

ARASTTIRMA MAKALESI

\title{
Yaşlı Nüfusun Sosyo-Ekonomik Hayata Uyumunda İleri Yaş Eğitiminin Önemi
}

Doç. Dr. Seda TEKELİ, Anadolu Üniversitesi, İktisat Fakültesi, Eskişehir, e-posta: sakyalcin@anadolu.edu.tr

ORCID: https://orcid.org/0000-0003-1839-8291

\section{Öz}

Küresel ve ulusal düzeyde nüfusun demografik yapısındaki değişimin demografik ekonomik, sosyal, vb. birçok alanda yansımalarının hissedilmesi, nüfus yapısındaki değişime olan dikkatleri artırmıştır. Sürekli ve hızla değişen günümüz dünyasında yaşam tarzları, üretim yöntemleri, ekonomik düzen, yaşamsal gereklilikler vb. de bu sürekli ve hızlı değişimden nasibini almaktadır. Özellikle ortalama yaşam süresinin uzamasıyla birlikte nüfus içerisindeki payları her geçen gün artan ve artacak olan yaşlı nüfusun değişime uyumunu zorunlu kılmaktadır. Bu uyum da ancak eğitim ile mümkündür. Bu bağlamda yetişkinlerin değişen dünyaya uyumlu ve verimli bir şekilde yaşamalarını sağlayacak yolların öğretilmesi ve ileri yaş eğitimine gereken önemin verilmesi gerekmektedir. Bu çalışmanın amacı; toplam nüfus içerisinde payları her geçen gün artan yaşlı nüfusun yaşamsal ihtiyaçlarının çeşitli sosyal politika uygulamaları ile karşılanmasının yanı sıra onların değişen ekonomik ve sosyal yaşama uyumlarını artırarak kendi ihtiyaçlarını kendilerinin karşılamalarında önemli olduğu düşünülen "ileri yaş eğitiminin" etkisini incelemektir. Bu amaçla, öncelikle yaşlanma ve yaşlılık kavramları üzerinde durularak; nüfusa dair demografik veriler ve projeksiyonlar kapsamında Dünya'da ve Türkiye'deki yaşlanma süreci açıklanmaya çalışılacaktır. Sonrasında ise sosyo-ekonomik yaşama uyumda "ileri yaş eğitimi" nin yeri ve önemi tartışılmaya çalışılacaktır.

Anahtar Kelimeler: Demografik Değişim, Yaşlılık, Yetişkin Eğitimi, Nüfusun Yaşlanması, Sosyoekonomik Uyum.

Makale Gönderme Tarihi: 26.03.2020

Makale Kabul Tarihi: 01.06.2020

\section{Önerilen Atıf:}

Tekeli, S. (2020). Yaşlı Nüfusun Sosyo-Ekonomik Hayata Uyumunda İleri Yaş Eğitiminin Önemi, Sosyal, Beşeri ve İdari Bilimler Dergisi, 3(6): 399-422.

(C) 2020 Sosyal, Beşerî ve İdari Bilimler Dergisi. 


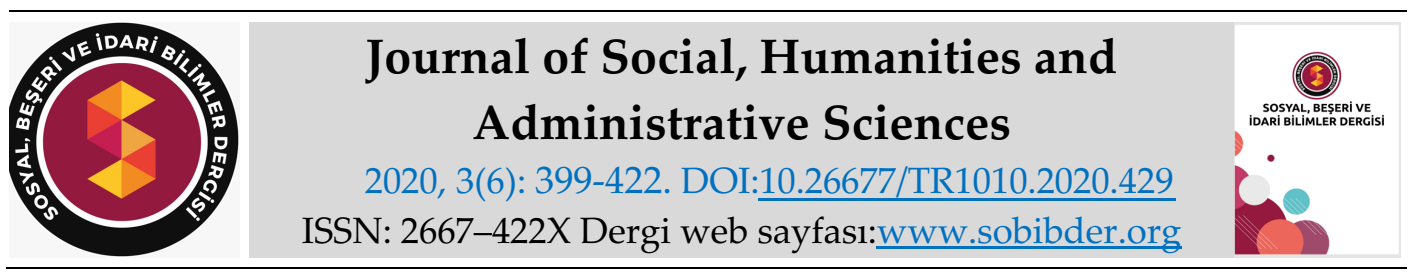

RESEARCH PAPER

\title{
The Importance of Advanced Age Education in Adaptation of Old Population to Socio-Economic Life
}

Associate Prof. Dr. Seda TEKELİ, Anadolu University, Faculty of Economics, Eskişehir, e-mail: sakyalcin@anadolu.edu.tr ORCID: https://orcid.org/0000-0003-1839-8291

\begin{abstract}
The demographic economic, social, etc. changes in the demographic structure of the population at the global and national level. Feeling their reflections in many areas increased the attention to the change in the population structure. In today's constantly changing world, life styles, production methods, economic order, vital requirements, etc. also gets its share from this constant and rapid change. Especially with the increase in the average life expectancy, the share of the elderly population, whose share in the population increases and will increase day by day, makes it obligatory to adapt to change. This harmony is only possible with education. In this context, it is necessary to teach the ways that adults can live in harmony and efficiently to the changing world, and to give importance to advanced education. The purpose of this study; In addition to meeting the vital needs of the elderly population, whose share in the total population increases day by day, with various social policy practices, it is to examine the effect of "advanced age education" which is thought to be important in meeting their own needs by increasing their adaptation to changing economic and social life. For this purpose, firstly, by emphasizing the concepts of aging and old age; the scope of demographic data and projections on population aging process will be explained in the world and Turkey. Afterwards, the place and importance of "advanced age education" in adaptation to socio-economic life will be discussed.
\end{abstract}

Keywords: Demographic Change, Ageing, Adult Education, Population Aging, Socio-Economic Adaptation.

Received: 26.03 .2020

Accepted: 01.06.2020

\section{Suggested Citation:}

Tekeli, S. (2020). The Importance of Advanced Age Education in Adaptation of Old Population to Socio-Economic Life, Journal of Social, Humanities and Administrative Sciences, 3(6): 399-422.

(c) 2020 Sosyal, Beşerî ve İdari Bilimler Dergisi. 


\section{Gíriş}

Dünya genelinde nüfusun yaşlanması ile ilgili olarak benzeri olmayan bir süreç yaşanmaktadır. Geçmişe ait doğum ve ölüm oranlarındaki değişime bakıldığında, günümüzde doğurganlık oranları düşmekte, yaşam beklentisi artmakta ve tüm bunlar küresel yaş yapısının değişimine ve demografik dönüşümün gerçekleşmesine neden olmaktadır. 21. yy.'da bütün dünyada insanlar daha uzun bir yaşam sürmektedir. Bu bağlamda küresel yaşlanma süreci ya da diğer bir ifadeyle demografik dönüşümün gerçekleştiği görülmektedir. Nüfus projeksiyonlarına göre, 2020 yılında 60 yaş ve üstü insan sayısının bir milyar, 2050 yılında ise iki milyar olacağı tahmin edilmektedir. Küresel ve ulusal düzeyde nüfusun demografik yapısındaki değişimin demografik ekonomik, sosyal, vb. birçok alanda yansımalarının hissedilmesi, nüfus yapısındaki değişime olan dikkatleri artırmıştır (Günsoy ve Tekeli, 2015: 36).

Günümüzde, özellikle nüfusun yaşlanmasının daha fazla hissedildiği gelişmiş ülkelerde, yaşlı nüfusun sosyal ve ekonomik yaşamdan uzaklaştırılmadan yaşamlarını devam ettirmelerine yönelik çalışmalar artış göstermiştir (Uyanık, 2017: 68). Sürekli ve hızla değişen günümüz dünyasında yaşam tarzları, üretim yöntemleri, ekonomik düzen, yaşamsal gereklilikler vb. de bu sürekli ve hızlı değişimden payını almaktadır. Özellikle ortalama yaşam süresinin uzamasıyla birlikte nüfus içerisindeki payları her geçen gün artan ve artacak olan yaşlı nüfusun değişime uyumunu zorunlu kılmaktadır. Bu uyum da ancak eğitim ile mümkündür. Bu bağlamda yetişkinlerin değişen dünyaya uyumlu ve verimli bir şekilde yaşamalarını sağlayacak yolların öğretilmesi gerekmektedir (Kılavuz, 2002: 60).

\section{YAŞLILIK: Kavram ve Teoriler}

İnsanoğlunun yaşam dönemlerini bebeklik, çocukluk, ergenlik, gençlik, olgunluk ve yaşlılık olarak sıralamak mümkündür. Toplumların tarihsel gelişim süreci içerisinde, yaşlılar toplum içerisindeki diğer bireylerle sahip olunan haklar bakımından eşit olarak değerlendirilmemişlerdir. 16. ve 17. yüzyıllarda yaşlılık, sakatlık ile eşdeğer bir süreç olarak nitelendirilirken; 20. yüzyılda ise sosyal anlamda toplumun dışında bırakılmışlardır (Tufan, 2002: 20). Son yıllarda Dünya nüfusunun giderek yaşlanması ve yaşlılık döneminin ortalama yaşam süresi içerisinde uzun bir dönemi kapsaması hem Dünya'da hem de Türkiye'de yaşlılık kavramı ve olgusunun daha fazla ele alınmasını da beraberinde getirmiştir.

Toplumsal yaşam içerisinde, canlı doğan her birey biyolojik gelişimin belirli basamaklarında ilerlemektedir. Yaşlılık bu basamaklardan biridir, ancak tüm bireylerin bu basamağa ulaşması kimi zaman mümkün olmayabilir. Bu nedenledir ki, yaşlılık muhtemel niteliktedir. Bireylerin kalıtımla getirdiği özellikleri, beslenme alışkanlıkları, yaşamlarını sürdürdükleri çevre koşulları ve kişisel çabaları daha erken ya da daha geç bir dönemde yaşlılık ile karşılaşmalarını etkileyebilmektedir (DPT, 2007: 10).

Yaşlılık kavramının, literatürde ve günlük konuşmada kimi zaman yaşlanma kavramı yerine kullanıldığı da gözlenmektedir. Her iki kavram, kimi zaman, birbirine benzer olarak değerlendiriliyor olsa da anlam olarak farklıdır. Yaşlılık bir durum ya da bir olguyu ifade ederken; yaşlanma ise bir süreci ifade etmektedir. Şöyle ki, yaşlılık kavramı daha çok bir olgu olarak, toplumda belirli bir yaşın üzerindeki bireyleri tarif edebilmek için kullanılırken; yaşlanma kavramı ise biyolojik boyutun ötesinde toplumsal boyutu olan bir durumu ve süreci kapsamaktadır (Korkmaz ve Korkut, 2018: 259). Ayrıca yaşlılık, bireylerin doğdukları günden başlayarak her yıl yaş almanın bütünsel bir hali olarak da ifade edilebilmektedir (Ceylan, 2015:4). Bu nedenledir ki, yaşlanma bir hastalık değildir sadece büyüme ve olgunluğa erişme anlamına gelmektedir (Arpacı, 2005: 16). Diğer bir ifadeyle yaşlılık, bireyin bedensel performans ve 
canlılığının azaldığı bir dönemi işaret ederken; yaşlanma ise bireyin dünyaya geldiği andan başlayarak ölümüne gelinceye kadar ki dönemi kapsamaktadır (Uyanık, 2017: 70). Peki yaşlılık nedir? Günlük yaşamımız içerisinde biz kimlere yaşlı deriz? Bireyler ne zaman yaşlanır ve yaşlı olur? Tüm bu sorulara günümüz dünyasında ortalama yaşam süresinin uzamasıyla birlikte cevap bulunmaya çalışılmaktadır.

Yaşlılık kavramının tek ve genel bir tanımını yapabilmek güçtür. Toplumların yapılarına, kişilerin özelliklerine ve hatta içinde bulunulan zaman dilimine göre farklı yaşlılık tanımlamaları yapmak mümkündür. İklim, beslenme alışkanlıklarındaki farklılıklar, çalışılan işin nitelikleri ve demografik özellikler evrensel ve değişmez bir yaşlılık tanımı yapılmasını güçleştirmektedir (Altan ve Şişman, 2003: 5). Türk Dil Kurumu'na göre sözlük anlamıyla yaşlılık, yaşlı olma hali; ilerlemiş yaşın etkilerini gösterme durumu olarak tanımlanmaktadır (https://sozluk.gov.tr/?kelime=). Bir diğer tanımlamaya göre ise yaşlılık, bireyin doğduğu günden itibaren olgunlaşmasını tamamlayarak yaşamsal fonksiyonlarının yavaşlaması, aksaması ya da bozulması ve bireyin beklenen yaşam süresinin sonuna yaklaşmasıdır (Karan, 2007: 19).

Bir diğer tanımlamada ise yaşlılık, zayıflık ve muhtaçlık durumuyla ilişkilendirilmekte ve bireylerin içinde bulunmak istemedikleri ya da yaklaşmak istemedikleri bir dönem olarak nitelendirilmektedir (Harwood, 2007:6; Çolak ve Özer, 2015: 116). Yaşlılığın, biyolojik, kronolojik ve sosyal yönlerinin varlığı, yaşlılığı çok yönlü ve karmaşık hale getirmektedir (Özer ve Karabulut, 2003: 73; Çolak ve Özer, 2015: 116).

"Üçüncü yaş dönemi"; "altın çă̆"; ve "yeşil yıllar" olarak da adlandırılan yaşlılık, farklı disiplinler tarafından farklı yönleriyle ele alınmakta ve tanımlanmaktadır (Arpacl, 2005: 16; Ceylan, 2015: 29). Yaşlılık kavramı bazı tanımlamalarda kronolojik yaş ya da takvim yaşı üzerinden açıklanmaya çalışılmaktadır. Genellikle ülkelerin kabul ettikleri yasal emeklilik yaşı ile ilişkilendirilerek yaşlılığın başlangıç dönemi belirlenmeye çalışılmaktadır. Dünya Sağlık Örgütü'ne göre yaşlılık ilerleyen yaşla birlikte bireyin içinde yaşadığı çevreyle olan uyum sağlama yeteneğinin azalmasıdır. Yapılan bu tanımlama çerçevesinde, Dünya Sağlık Örgütü'nün yaptığı yaş sınıflandırmasına göre, 0-17 yaş arası ergen; 18-65 yaş arası genç; 66-79 yaş arası orta yaş; 80-99 yaş arası yaşlı ve 100 yaş ve sonrası ise ihtiyarlık olarak kabul edilmektedir (WHO, 2017).

Yaşlılık kavramını farklı boyutlarıyla da ele almak mümkündür. Araştırmalar yaşlılığın dört temel boyutu olduğunu göstermektedir; biyolojik, psikolojik, sosyolojik ve fonksiyonel. Yaşlılığın biyolojik boyutu, psikolojik ve sosyal boyutundan önce başlamaktadır. Biyolojik yaşlılık, en genel yaklaşımla "bireyin sağlık durumuna, çevre şartlarına, yaşanılan yer ve zamana göre değişiklikler göstermesi" olarak tanımlanırken; bireyin öğrenme, ezberleme ve duygusal alanlarda hassaslaşması ya da zayıflaması psikolojik yaşlııı; bireylerin sahip oldukları beceri ve yeteneklerini içinde yaşadıkları toplumda yeterli düzeyde kullanamaması fonksiyonel ve toplumla uyum sorunu yaşaması ise sosyal yaşlılık olarak ifade edilmektedir. Yaşlılığın tüm boyutları aynı zamanda yaşlılığın neden sorun olarak algılandığının da temel göstergeleridir. Yaşlılıkla birlikte bireylerin biyolojik yapılarının (kas ve iskelet sistemi, organların işlevselliği, bağışıklık sistemi vb.) bozulmaya başlaması; toplumda günlük yaşamda uyum zorluğunun yaşanmaya başlanması, ihmal, yabancılaşma, dışlanma ya da ayrımcı davranışlar yaşlılığın temel sosyal sorunları olarak tanımlanmaktadır. Ancak yaşlılığın bu belirtenleri ve sonuçları ülkelerin gelişmişlik düzeylerine ve toplumların yapısına göre değişkenlik gösterebilmektedir. $\mathrm{Bu}$ nedenledir ki toplumların bazılarında yaşlılık olağan bir süreç olarak değerlendirilmekte; bazı toplumlarda ise politikalar yaratılması gereken bir sorun olarak değerlendirilebilmektedir (İçli, 2004: 5). 
Yaşlılığın bir diğer boyutunu oluşturan psikolojik yaşlılık ise, biyolojik değişimlerin ötesinde bireyin yaşa bağlı olarak davranışsal uyum yeteneğindeki değişme olarak tanımlanmaktadır (Arpac1, 2005: 18). Buna ilave olarak, "hissedilen yaş" olarak da nitelendirilen yaş, psikolojik anlamda bireylerin bilişsel becerileri ve ruhsal davranışlarında meydana gelen değişimlerdir (Asi-Karakaş ve Durmaz, 2017: 33). Bu bağlamda yaşlılık, biyolojik ve psikolojik anlamda bir gerileme dönemi olarak değerlendirilmektedir (Arpac1, 2005: 22). Yaşlılı̆̆ın daha iyi anlaşılabilmesi için, kavramın sosyolojik açıdan da ele alınması önemlidir. Yaşlılık üzerine yapılan tanımlamalardan belki de en ilginç olanı sosyolojik yaşlılıktır. Sosyolojik yaşlılık, içinde yaşanılan toplumun norm, değer ve tutumlarından etkilenmektedir (Macrucol, 2005: 5; Komşu, 2014: 372; Arpac1, 2005: 20). Sosyolojik yaşlılık üzerine araştırmalar gerçekleştiren sosyal gerentolog Bernice Neugarten'e göre, tüm toplumlarda yaş, statü ve toplumsal etkileşim bakımından önemlidir ve evlenmeden çocuk sahibi olunmasına, çalışmaya başlamadan emekli olunmasına kadar her alanı etkilemektedir. Bu bağlamda Neugarten yaşı "toplumsal (sosyal) saatler - social clocks" olarak betimlemektedir (Macrucol, 2005: 6). Sosyolojik yaşl1lık genel olarak "bireyin ve toplumun yaşlanma sürecinde birbirini etkilemesi" olarak tanımlanmakta (Canatan, 2008: 16; Ceylan, 2015: 31) ve yaşlanmayla beraber toplumsal rolün, statünün ve beklentilerin değişmesi olarak değerlendirilmektedir (Er, 2009: 135; Ceylan, 2015: 31). Bir diğer ifadeyle sosyolojik yaşlılık, toplumun yaşlılara verdiği değer ile toplumun yaşlılardan beklediği davranışlar özelinde ele alınmaktadır (Arpacı, 2005: 21).

Yapılan çalışmalar göstermektedir ki, yaşlılı̆g 1 üç ana dönem içerisinde ele almak mümkündür. Bunlar, düşkün yaşlılık; pasif yaşlılık ve aktif (dinç) yaşlılıktır. Düşkün yaşlılık dönemi, ekonomik, kültürel ve toplumsal nedenlerle yaşanılan düşkünlükler olarak nitelendirilirken; pasif yaşlılık dönemi ise bireylerin üretime ya da herhangi bir etkinliğe katılmaksızın pasif bir yaşam sürdükleri dönem olarak adlandırılmaktadır. Aktif yaşlılık dönemi ise, her ikisinden farklı olarak ekonomik, toplumsal, siyasal ve kültürel anlamda etkin olarak yaşanılan bir dönemi ifade etmektedir (Dülger, 2012: 37).

Yaşlılık, yakın zamana kadar yalnızca gelişmiş ülkelerin demografik bir sorunu iken; günümüzde gelişmekte olan ülkelerin ve hatta tüm Dünyanın temel bir nüfus sorunu halini almıştır. Yaşlılığın ne olduğu ve insanların hangi durumlarda ve neden yaşlı olarak sınıflandırıldıklarına dair literatürde pek çok teori yer almaktadır. Teorilerin sayısal olarak çok olmasının nedeni, her bir teorinin yaşlılık kavramına farklı bir pencereden bakmasıdır. Yaşlılığ 1 biyolojik bir olgu olarak ele alan teoriler; aşınma ve yıpranma teorisi, otoimmün teori, crosslinkage teorisi, serbest radikal teori ve hücresel yaşlanma teorisidir. Aşınma ve yıpranma teorisine göre, organizmalar makinelere benzemektedir. Makineler gibi organizmalar da zamanla aşınmakta ve yıpranmaktadır. Otoimmün teori ise, yaşlılıkla birlikte insanların bağışıklık sistemlerinin kendi vücutlarına karşı çalıştığını ve bu nedenle kanser, romatizmal hastalıklar ve diyabet gibi hastalıkların yaşlılıkta daha sık gözlendiğini belirtmektedir. Cross-linkage teorisi ise, ilerleyen yaşla birlikte kollajen adlı proteinin geçirdiği değişimin yaşlanma bulgularına yol açtı̆̆ını vurgulamaktadır. Biyolojik temelli bir diğer teori olan serbest radikal teori, zamanla biriken serbest radikallerin hücresel moleküllere hasar verdiğini ve bunun da insan DNA'sında mutasyona neden olduğunu ileri sürerken; hücresel yaşlanma teorisine göre ise, hücreler zaman içerisinde sınırlı sayıda çoğalabilmektedir ve bu da yaşlanmanın temel göstergelerindendir (Aile ve Sosyal Politikalar Bakanlığı, 2012: 24).

Yaşlılığı sosyal yaşamda yaşanılan eksiklik ve yoksunlukların bir sonucu olarak değerlendiren sosyal alan teorileri ise; ilgisizlik teorisi, aktivite teorisi, süreklilik teorisi, alt kültür teorisi, alışveriş teorisi ve modernizasyon teorisidir. İlgisizlik teorisine göre, normal yaşlanma süreci bireylerin içinde bulunduğu sosyal sistemden kopması ve görev ile sorumluluklarını ilerleyen yaş ile birlikte bırakmasıyla devam etmektedir. Aktivite teorisi ise, yaşlıların psikolojik ve sosyal 
gereksinimlerinin diğer yaş gruplarından farklı olmadığını vurgulamaktadır. Yaşlıların toplumdan kopmalarının ve uzaklaşmalarının sebebini ise yaşın ilerlemesiyle birlikte artan sağlık sorunları olarak görmektedir. Bir diğer sosyal alan teorisi olan süreklilik teorisi ise, bireylerin kişilik özelliklerinin yaşlanmaya uyum sağlamada etkili olduğunu ve kişiliğin, aktivitelerin ve ilişkilerin bireyleri yaşlanmanın olumsuz etkilerinden koruyacağına inanmaktadır. Alt kültür teorisi ise, yaşlıların gençler tarafından dışlanmalarının sebebinin, yaşlıların kendi ortak sorunları ve ilgi alanlarından dolayı kendi içlerinde bir alt kültür oluşturmaları olduğunu savunmaktadır. Alışveriş teorisi, yaşlılar ile gençler arasındaki ilişkinin zaman içerisinde azalmasını kuşaklar arasındaki maddi ve fiziksel paylaşımın azalması ile ilişkilendirirken; modernizasyon teorisi ise, modernleşme sonrasında gerek günlük yaşamda gerekse çalışma yaşamında gerçekleşen değişime yaşlıların uyum zorluklarının, yaşlıların toplumdaki saygınlıklarının azalmasına neden olduğunu vurgulamaktadır (Aile ve Sosyal Politikalar Bakanlığı, 2012: 25).

Günlük yaşam içerisinde yaşlılığın ölüme en yakın dönem olarak değerlendirilmesi; ülkelerin genç bir nüfusa sahip olmalarının önemli bir değer olarak vurgulanması; yaşlıların ekonomik sisteme üretim faktörü olarak katkılarının sınırlı ya da hiç olamaması ve yaşlılara ve yaşlılığa yönelik toplumsal önyargı ve değişmez tabular yaşlılığın bir sosyal sorun olarak değerlendirilmesine neden olmaktadır.

\section{NÜFUSUN YAŞLANMASI}

\section{Dünya'da Nüfus Hareketleri}

İnsanlık tarihinin başlangıcından günümüze kadar gelen dönem içerisinde dünya nüfusu daima artış eğilimi içerisinde olmuştur. Bir nüfusun yaş yapısının değişmesi, nüfus içerisinde çocuklar ve gençlerin payının azalmasıyla ve yaşlı (65 yaş ve üzeri) nüfusun artmasıyla mümkündür. Kaba doğum ve ölüm oranlarındaki azalmayla birlikte nüfus yapısında meydana gelen bu değişim "demografik dönüşüm" olarak ifade edilmektedir (Mandıracıoğlu, 2010: 39). 1800'lü yıllarda 1 milyar olan dünya nüfusu, 2000 yıllarda 6 milyara (Uyanık, 2017: 72); 2019 yılında ise 7,7 milyara ulaşmıştır. 20. yy.'dan önceki dönemde dünyada nüfus artış hızı sonraki yıllar ile karşılaştırıldığında daha düşük, nüfus durağan ve toplam nüfus içerisinde 65 yaş üstü bireylerin oranı daha az iken; 20. yy.'dan sonraki dönemde ise ortalama yaşam süresinin uzaması, kaba doğum ve ölüm oranlarının azalması ile dünya nüfusu artış eğilimi içerisine girmiştir (Yüceşahin, 2011: 11). Dünya nüfusunda artışla birlikte nüfusun yaşa göre dağılımını gösteren nüfus piramidinde de değişimler meydana gelmiştir. Öyle ki, dünyada yaşlı nüfusun artış hızının, tüm dünya nüfusunun artış hızından daha hızlı olduğunu söylemek mümkündür (Uyanık, 2017: 73). Son 50 yıllık zaman dilimi içerisinde, dünyada toplam nüfus 2,4 oranında artarken; yaşlı nüfus ise 3,2 kat artış göstermiştir (Deivitt-Thomas, 1996: 2). 1950 yılından başlayarak takip eden 100 yıllık bir dönem için yapılan nüfus projeksiyonları göstermektedir ki, 2050 yılına ulaşıldığında dünya nüfusu 4 kat artarken; yaşlı nüfusun ise 10 kat artmış olacağı beklenmektedir (Kinsella ve Wan, 2009). 




Şekil 1. Dünya Nüfus Piramidi, 2020

Kaynak: https://www.worldlifeexpectancy.com/tr/world-population-pyramid

Dünya Sağlık Örgütü 2017 yılı “Dünya Sağlık ve Yaşlılık Raporu”na göre, nüfusun yaşlanmasının iki temel nedeni vardır. Bunlardan biri tüm dünyada ortalama yaşam süresinin uzaması; bir diğer ise doğum oranlarının düşmesidir (WHO; 2017).

Dünya genelinde ve bölgeler özelinde nüfus yoğunluklarını gösteren aşağıdaki Tablo 1'de geçmişten günümüze ve hatta nüfus projeksiyonlarına göre gelecekte nüfusun artış hızı net olarak göstermektedir. Buna göre, 2019 yılında 7,6 milyara yakın olan Dünya nüfusunun; 2030 yılında 8,5 milyara, 2050 yılında 9,7 milyara ve 2100 yılında ise 10,8 milyara yükseleceği öngörülmektedir. 2019 yılı itibariyle dünya nüfusunun yaklaşık olarak 1,1 milyarı Afrika ülkelerinde; 4,8 milyarı Asya ülkelerinde; 1,1 milyarı Avrupa ve Kuzey Amerika ülkelerinde; 648 milyonu Latin Amerika ve Karayiplerde ve 42 milyonu ise Okyanusya'da yaşamaktadır (UN, 2019: 23).

Tablo 1. Bölgelere Göre Dünyada Nüfus Değişimi, 2019

\begin{tabular}{|l|c|c|c|c|c|c|}
\hline \multirow{2}{*}{ Bölgeler } & \multicolumn{6}{|l|}{ Nüfus (Milyon) } \\
\cline { 2 - 7 } & $\mathbf{1 9 5 0}$ & $\mathbf{2 0 1 7}$ & $\mathbf{2 0 1 9}$ & $\mathbf{2 0 3 0}$ & $\mathbf{2 0 5 0}$ & $\mathbf{2 1 0 0}$ \\
\hline DÜNYA & $\mathbf{2 . 5 3 6}$ & $\mathbf{7 . 5 5 0}$ & $\mathbf{7 . 7 1 3}$ & $\mathbf{8 . 5 4 8}$ & $\mathbf{9 . 7 3 5}$ & $\mathbf{1 0 . 8 7 5}$ \\
\hline Afrika & 229 & 1.256 & 1.066 & 1.400 & 2.118 & 3.775 \\
\hline Asya & 1.404 & 4.504 & 4.843 & 5.263 & 5.661 & 5.225 \\
\hline $\begin{array}{l}\text { Avrupa ve Kuzey } \\
\text { Amerika }\end{array}$ & 722 & 1.103 & 1.114 & 1.132 & 1.136 & 1.120 \\
\hline $\begin{array}{l}\text { Latin Amerika ve } \\
\text { Karayipler }\end{array}$ & 169 & 646 & 648 & 706 & 762 & 680 \\
\hline Okyanusya & $13^{*}$ & 41 & 42 & 48 & 57 & 75 \\
\hline
\end{tabular}

* Hesaplamalarda Avusturya ve Yeni Zelanda ülkeleri hariç tutulmuştur.

Kaynak: United Nations, (2019). World Population Prospects, The 2019 Revision, s.23.

Dünya nüfusunun yaş gruplarına göre dağılımını ise Tablo 2' de görmek mümkündür. Buna göre, 2020 yılından 2100 yılına kadar sırasıyla 0-14 yaş aralığındaki nüfusun \%25,4'den \%24,5'e düşeceği; 15-59 yaş aralığındaki nüfusun \%61,0'dan \%41,4'e düşeceği; 60 yaş ve üzeri yaş 
grubundaki nüfusun $\% 13,5^{\prime}$ den $\% 9,9^{\prime}$ a düşeceği ve 80 yaş ve üzeri yaş grubundaki nüfusun ise $\% 1,9^{\prime}$ dan $\% 7,2^{\prime}$ ye yükseleceği beklenmektedir.

Tablo 2. Dünya Nüfusunun Yaş Gruplarına Göre Dağılımı (\%)

\begin{tabular}{|l|l|l|l|}
\hline \multirow{2}{*}{ DÜNYA } & \multicolumn{3}{|c|}{ Yillar } \\
\cline { 2 - 4 } & $\mathbf{2 0 2 0}$ & $\mathbf{2 0 5 0}$ & $\mathbf{2 1 0 0}$ \\
\hline $0-14$ & 25,4 & 18,6 & 24,5 \\
\hline $15-59$ & 61,0 & 41,4 & 41,4 \\
\hline $60+$ & 13,5 & 13,6 & 9,9 \\
\hline $80+$ & 1,9 & 2,4 & 7,2 \\
\hline
\end{tabular}

Kaynak: United Nations, World Population Prospects, 2019.

Tablo 1 ve Tablo 2 göstermektedir ki, dünya genelinde nüfus, artış eğiliminde olmakla birlikte, bu artışın önemli bir bölümünü ise yaşlı nüfusta yaşanan artış oluşturmaktadır. Elbette, ülkelerin gelişmişlik düzeylerine göre ülke nüfuslarının yaş gruplarına göre dağılımı farklılık gösterebilmektedir. 2019 yllı için gelişmiş ülkelerde toplam nüfusun \%16,4'ünü 0-14 yaş aralığındaki bireyler; \%11,1'ini 15-24 yaş aralığındaki bireyler; \%53,5'ini 25-64 yaş aralığındaki bireyler ve \%18,9'unu ise 65 yaş ve üzeri yaş grubundaki bireyler oluşturmaktadır. Az gelişmiş olan ülkelerde ise bu oranlar sirasıyla, \%27,4; \%16,5; \%48,9 ve \%7,2' dir (UN, 2019: 6-10).

Dünya'da nüfusun yaşlanmasının diğer temel göstergeleri ise, doğurganlık oranının azalması ile ortalama yaşam süresinin artmasıdır. Bir önceki bölümde de ifade edildiği üzere, doğum oranlarındaki azalma ve yaşanan ortalama yaşam süresindeki artış beraberinde pek çok sorunu da getirmiştir. Bunları, yaşlı bağımlılık oranının artması, aktif nüfusun azalması, sosyal güvenliğin finansman güçlükleri, sosyal yardım ve hizmet alanında yatırım harcamalarının artması vb. sıralamak mümkündür (Korkmaz ve Korkut, 2018: 262).

Tablo 3. Dünyada Bölgelere Göre Toplam Doğurganlık Sayıları, 1985-2050

\begin{tabular}{|c|c|c|c|c|c|c|c|c|c|c|c|c|c|}
\hline \multirow{2}{*}{ Bölgeler } & \multicolumn{13}{|c|}{ Yillar } \\
\hline & \begin{tabular}{|l|}
$1985-90$ \\
\end{tabular} & $1990-95$ & 1995-00 & $2000-05$ & $2005-10$ & 2010-15 & 2015-20 & $2020-25$ & 2025-30 & $2030-35$ & 2035-40 & $2040-45$ & $2045-50$ \\
\hline DÜNYA & 3,44 & 3,01 & 2,78 & 2,65 & 2,58 & 2,52 & 2,47 & 2,54 & 2,62 & 2,70 & 2,77 & 2,85 & 2,95 \\
\hline \begin{tabular}{|l|} 
Afrika \\
\end{tabular} & 6,19 & 5,72 & 5,35 & 5,08 & 4,90 & 4,73 & 4,44 & 4,48 & 4,53 & 4,57 & 4,61 & 4,65 & 4,69 \\
\hline Asya & 3,50 & 2,90 & 2,61 & 2,45 & 2,33 & 2,21 & 2,15 & 2,18 & 2,22 & 2,24 & 2,25 & 2,27 & 2,30 \\
\hline Avrupa & 1,81 & 1,57 & 1,43 & 1,43 & 1,56 & 1,60 & 1,61 & 1,61 & 1,62 & 1,63 & 1,64 & 1,64 & 1,64 \\
\hline $\begin{array}{l}\text { Latin Amerika ve } \\
\text { Karayipler }\end{array}$ & 3,45 & 3,08 & 2,77 & 2,49 & 2,26 & 2,14 & 2,04 & 2,06 & 2,07 & 2,08 & 2,09 & 2,09 & 2,10 \\
\hline Kuzey Amerika & 1,88 & 2,00 & 1,95 & 1,99 & 2,01 & 1,85 & 1,75 & 1,75 & 1,75 & 1,75 & 1,75 & 1,75 & 1,75 \\
\hline \begin{tabular}{|l|} 
Okyanusya \\
\end{tabular} & 2,53 & 2,52 & 2,48 & 2,46 & 2,54 & 2,44 & 2,36 & 2,40 & 2,42 & 2,43 & 2,45 & 2,47 & 2,50 \\
\hline
\end{tabular}

Kaynak: United Nations, World Population Prospects, 2019.

Tablo 3'de görüldüğü üzere, dünya genelinde doğurganlık sayısı gittikçe azalmaktadır. 19851990 yılları arası dönemde kadın başına düşen doğurganlık 3,44 iken; 2015-2020 döneminde ise bu sayı 2,47 'e düşmüştür. Bölgeler özelinde incelediğimizde ise, ele alınan tarihler itibariyle Afrika'da doğurganlık 6,19'dan 4,44'e; Asya'da 3,50'den 2,15'e; Avrupa' da 1,81'den 1,61'e; Latin Amerika ve Karayipler' de 3,45'den 2,04'e; Kuzey Amerika'da 1,88'den 1,75'e ve Okyanusya'da ise 2,53'den 2,36'ya düştüğü görülmektedir (UN, 2019). Söz konusu sayıların 2095-2100 yıllarına gelindiğinde ise Dünya genelinde 1,97'ye düşeceği tahmin edilmektedir. Aynı dönem için bölgelere göre tahmin edilen doğurganlık sayıları dağılımı ise şöyledir; Asya 1,81; Avrupa 1,84; 
Katin Amerika ve Karayipler 1,78; Kuzey Amerika 1,91 ve Okyanusya 1,86' dır. Bir diğer ifadeyle bölgeler özelinde tüm dünyada doğurganlık oranının incelenen dönemler itibariyle yaklaşık olarak yarısı oranında azalacaktır (Korkmaz ve Korkut, 2018: 262-263).

Birleşmiş Milletlerin nüfusa ait istatistiki veri tabanından yararlanılarak oluşturulan Tablo 3'e göre gelecek yıllar itibariyle kadın başına düşen doğurganlık sayısındaki azalma dünya nüfusunun yaşlanma eğilimi içerisinde olduğunun bir diğer göstergesidir. Ülkelerin sosyoekonomik gelişmişlik düzeyine göre farklılaşmakla birlikte kadın başına doğum oranları önemli ölçüde azalma göstermiştir. Afrika ve Ortadoğu ülkelerinde farklılık gösterse de yapılan araştırmalar göstermektedir ki, toplam doğurganlık kızı 1950'lerden günümüze yarı yarıya azalmıştır. 2017 yılı itibariyle tüm dünya ortalaması 2-3 çocuk aralığındayken; kadınların en çok çocuk sahibi olduğu ülkeler (5-7 çocuk aralığında) Nijer, Çad, Somali, Mali, Afganistan, Güney Sudan, Burkina Faso, Burundi, Uganda ve Angola olarak sıralamak mümkündür. Kadınların en az çocuk (1-2 çocuk aralığında) sahibi olduğu ülkeler Kıbrıs, Tayvan, Güney Kore, Andora, Puerto Rico, Tayland, Bosna Hersek, Polonya, Moldova ve Japonya'dır (bbc.com/turkce/haberler).

Nüfusun yaşlanmasında etkili olan bir diğer faktör ise, ortalama yaşam süresindeki artıştır. Tıp alanında teknolojik ve bilimsel anlamda teşhis ve tedavi konusunda yaşanan gelişmeler, ölüm oranlarının azalmasında ve ortalama yaşam süresinin uzamasında belirleyici olmuştur. Elbette $\mathrm{ki}$, ülkelerin gelişmişlik düzeylerindeki farklılıklara göre beklenen ortalama yaşam süresi de değişiklik göstermektedir. Ancak, dünya genelinde değerlendirildiğinde Birleşmiş Milletler nüfus projeksiyonlarına göre önümüzdeki 50 yıllık zaman dilimi içerisinde ortalama beklenen yaşam süresinin 30 yıl artacağ tahmin edilmektedir.

Tablo 4. Bölgelere Göre Dünyada Ortalama Yaşam Beklentisi (Yıl)

\begin{tabular}{|c|c|c|c|c|c|c|c|c|c|c|c|c|c|}
\hline \multirow{2}{*}{ Bölgeler } & \multicolumn{13}{|c|}{ Yillar } \\
\hline & $1985-90$ & $1990-95$ & 1995-00 & $2000-05$ & 2005-10 & 2010-15 & 2015-20 & 2020-25 & 2025-30 & $2030-35$ & $2035-40$ & $2040-45$ & $2045-50$ \\
\hline DÜNYA & 63,71 & 64,56 & 65,63 & 67,07 & 68,92 & 70,88 & 72,28 & 73,16 & 73,99 & 74,79 & 75,49 & 76,15 & 76,77 \\
\hline Afrika & 52,09 & 51,93 & 52,33 & 53,53 & 56,78 & 60,25 & 62,66 & 64,11 & 65,44 & 66,65 & 67,74 & 68,73 & 69,64 \\
\hline Asya & 63,46 & 64,98 & 66,55 & 68,33 & 70,03 & 71,83 & 73,28 & 74,20 & 75,05 & 75,83 & 76,55 & 77,23 & 77,89 \\
\hline Avrupa & 72,84 & 72,67 & 73,11 & 73,80 & 75,30 & 77,18 & 78,33 & 79,09 & 79,86 & 80,61 & 81,32 & 82,01 & 82,67 \\
\hline $\begin{array}{l}\text { Latin Amerika ve } \\
\text { Karayipler }\end{array}$ & 67,15 & 68,96 & 70,67 & 72,25 & 73,45 & 74,44 & 75,24 & 76,07 & 77,00 & 77,97 & 78,83 & 79,67 & 80,48 \\
\hline Kuzey Amerika & 75,07 & 75,85 & 76,68 & 77,42 & 78,44 & 79,23 & 79,15 & 79,50 & 80,23 & 81,32 & 82,04 & 82,75 & 83,44 \\
\hline Okyanusya & 71,06 & 72,58 & 73,62 & 74,91 & 76,25 & 77,35 & 78,44 & 79,25 & 79,90 & 80,50 & 81,03 & 81,53 & 82,00 \\
\hline
\end{tabular}

Kaynak: United Nations, World Population Prospects, 2019.

Tablo 4'de görüldüğü üzere, tüm dünyada yaşam beklentisinin artacağ 1 tahmin edilmektedir. 1985-1990 yılları arasındaki dönemde dünyada ortalama yaşam beklentisi 63,7 yıl iken; 2015-2020 yıllarda 72,2'ye yükseldiği görülmektedir. Projeksiyonlara göre 2050 yılına gelindiğinde yaşam beklentisinin 76,7'ye yükseleceği tahmin edilmektedir. 1985-1990 yılından 2015-2020 yılına gelindiğinde yaşam beklentisi bölgelere göre sirasıyla, Afrika'da 52,0'den 69,6'ya; Asya'da 63,5'ten 77,9'a; Avrupa'da 72,8'den 82,7'ye; Latin Amerika ve Karayipler'de 67,1'den 80,5'e; Kuzey Amerika'da 75,0'den 83,4'e ve Okyanusya'da ise $71,0^{\prime}$ dan $82,0^{\prime}$ ye artacağ 1 öngörülmektedir.

Dünyada yaşlı nüfus için nüfus artış hızı, genel nüfus artış hızının neredeyse iki katına yakındır. Dünyada yaşlı nüfusun nüfus artış hızı \%2,1 iken; genel nüfus artış hızı ise \%1,2 olarak belirlenmiştir. 
Nüfus istatistikleri ve projeksiyonları göstermektedir ki, nüfusun yaşlanması, gelişmekte olan ülkelerde gelişmiş ülkelerden daha fazladır. Bunun nedeni ise, gelişmekte olan ülkelerde doğurganlık oranındaki azalma ile ileri teknoloji ve sağlık alanındaki gelişmeler sonrasında ortalama yaşam süresinin daha hızlı yükselmiş olmasıdır (WHO, 1998). Bilim ve teknolojinin gelişmesi ile sağlık sektöründe devrim niteliğindeki ilerlemeler (teşhis ve tedavi alanında), anne, çocuk ve bebek ölümlerinin azalması ve genel olarak sağlıklı yaşam alışkanlıklarının toplum içerisinde yaygınlaşmaya başlaması, bireylerin yaşam kalitelerini ve ortalama yaşam sürelerini artırmıştır (Arpacı, 2005: 26). Gelişmiş ve gelişmekte olan ülkeler bakımından nüfusun yaşlanma hızındaki farklılıklar nüfus içindeki bağımlılık oranları bakımından da farklılık göstermektedir. Kaba doğum oranlarının önemli ölçüde gerilediği ülkelerde, genç bağımlılık oranının* da düştüğü ve yaşlı bağımlılık oranının ise yükseldiği gözlenmektedir. Yaşlı bağımlılık oranının dünya genelinde 2025 yılında 53; 2050 yılında ise 58 olacağ tahmin edilmektedir. Gelişmekte olan ülkelerdeki bu artışın gelişmiş ülkeler de gözleneceği ve 2050 yılında yaşlı bağımlılık oranının 73 olacağı öngörülmektedir (UN, 2002: 45).

Dünya Sağlık Örgütü, "Herkes İçin Sağllk-21 Hedef (Health 21- Health For all in the 21st Century)" çalışmasında hedeflerden 5.'sinin yaşlıların sağlığı ile ilgili olduğunu açıklamıştır. Hedef 5'e göre, "2020 yılına kadar, 65 yaşın üzerindeki insanlar sağllk potansiyellerinin tam yerinde olmast firsatına sahip olmalı ve aktif sosyal rol oynayabilmelidirler. Özellikle yaşam beklentisinde ve 65 yaşının da sakatlık olmadan yaşama beklentisinde en az \%20 artış să̆lanmahıdı"." Bu bağlamda, Dünya Sağlık Örgütü nüfusun yaşlanmasına dikkat çekmiş bulunmaktadır (WHO, 2017: 16). Özetle, geçmiş yıllarla karşılaştırıldığında, dünya yaşlı bir nüfus potansiyeline sahiptir.

\section{Türkiye'de Nüfus Hareketleri}

Dünyada doğum ve ölüm oranlarının değişmesiyle yaşanılan nüfus yapısındaki değişim, yaşam sürelerinin uzaması nüfusun yaşlanma yönünde değişim göstermesine neden olmuştur. Günümüzde Dünya genelinde kaba doğum oranının azalması ve nüfus projeksiyonlarının bu azalma eğiliminin devam edeceği yönündeki tahminler yaşlı nüfusun artmasına neden olmaktadır. Dünyada yaşanan bu değişim Türkiye nüfus yapısında da değişimlerle yansımalarını göstermektedir (DPT, 2007; HÜNEE, 2019; Tekin ve Kara, 2018: 223).

Türkiye 1950'li yıllardan sonraki dönemde doğurganlık hızlarındaki azalma ile birlikte nüfus yaşlanma süreci içerisine girmiştir. 1950'li yıllardan sonra Türkiye'de kırdan kente yaşan göç hareketliliği, sağlık alanındaki gelişmeler, eğitim düzeyindeki artış ve kadının çalışma yaşamında yer almaya başlaması gibi nedenler toplam doğurganlık hızının yavaşlamasına neden olmuştur (DPT, 2007; HÜNEE, 2019; Tekin ve Kara, 2018: 223). Cumhuriyetin ilanını takip eden yıllarda, savaşın nüfusun üzerinde yol açtığı yıkımı düzeltebilmek adına doğum oranlarını artırmaya yönelik teşvik edici politikalar uygulanmış ancak, takip eden yıllarda bu politikalardan uzaklaşılmıştır. 1970’li yıllarda ise nüfustaki azalma eğilimi devam etmiştir.

Türkiye'de yaşlıların sosyo-ekonomik hayata katılımlarına dair saptamalar yapabilmek için Türkiye'nin demografik yapısına bakmakta fayda bulunmaktadır. Türkiye İstatistik Kurumu'nun (TÜIK) 2018 yılı Adrese dayalı Nüfus Kayıt Sistemi sonuçlarına göre Türkiye nüfusu 2018 yılında, bir önceki yıla göre 1 milyon 193 bin 357 kişi artmış ve Türkiye nüfusu 82

\footnotetext{
* Genç bağımlılık oranını; Çalışma çağı nüfusunu oluşturan 15-64 yaş kitlesinden, her 100 kişiye karşılık gelen toplumdaki 0-14 yaş aralığını ifade eder.

+ Yaşlı bağımlılık oranı; 15-64 yaş aralığındaki yetişkin nüfustaki her 100 kişi için 65+ nüfus gurubundaki insan sayısı yaşlı bağımlılık oranı olarak isimlendirilir
} 
milyonu (82.003.882) aşmıştır. 2018 yılı için Türkiye'de nüfus artış hızı \%o 14,7 olmuştur. Toplam nüfusun \%50,2'sini erkekler; \%49,8'ini ise kadınlar oluşturmaktadır. 2017 yılında 31,7 olan ortalama yaş; 2018 yılında 32 olmuştur. Ortalama yaş erkeklerde 31,4 iken; kadınlarda 32,7'dir (Bkz. Şekil 2 ve 3)

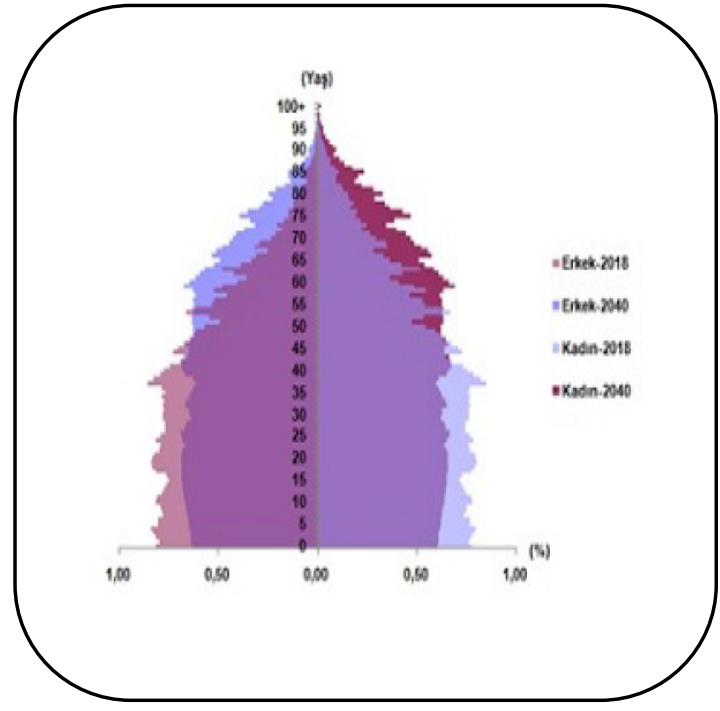

Şekil 2. Nüfus Piramidi, 2018-2040

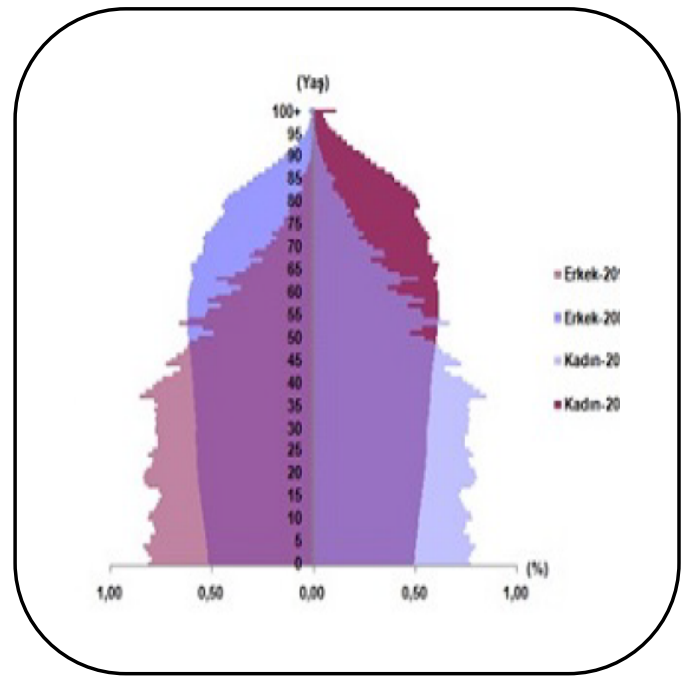

Şekil 3. Nüfus Piramidi, 2018-208

Kaynak: TÜIKK, Haber Bülteni, Nüfus Projeksiyonları, 2018-2080, (21 Şubat 2018).

2018 yılı için 15-64 yaş aralığında yer alan çalışma çağındaki nüfus bir önceki yıla göre \%1,4 oranında artmıştır. Buna göre, çalışma çağındaki nüfusun oranı ise $\% 23,4 ; 65$ yaş ve daha yukarı yaştaki nüfusun oranı ise $\% 8,8$ olarak gerçekleşmiştir.

2023 yılında 84.217.088 kişi olacağı tahmin edilen Türkiye nüfusunun; 2050 yılında ise 90 milyonu (93.475.575) aşacağı tahmin edilmektedir. 2050 yılından sonra ise artışın azalma eğilimine gireceği ve nüfusun 2075 yılında, 89.172.088 kişi olması tahmin edilmektedir. (Bkz.TÜİK, Nüfus Projeksiyonlar1, 2013-2075).

2018 yılında \%8,8 olan yaşlı nüfus oranının 2023 yılında \%10,2’ye yükseleceği ve ortanca yaşın da $34,6^{\prime}$ ya ulaşacağı beklenmektedir. Ortanca yaşa ilişkin bir diğer tahmin ise 2050 yılında ortanca yaşın 42,9; 2075 yılında ise 47,4 olacağı yönündedir (Bkz. Tablo 5).

Tablo 5. Ortanca Yaş, 2012-2075

\begin{tabular}{|l|l|l|l|}
\hline Yillar & Toplam & Erkek & Kadın \\
\hline 2012 & 30,1 & 29,5 & 30,6 \\
\hline 2023 & 34,0 & 33,3 & 34,6 \\
\hline 2050 & 42,9 & 41,8 & 44,0 \\
\hline 2075 & 47,4 & 46,0 & 48,7 \\
\hline
\end{tabular}

Kaynak: TÜİK, Haber Bülteni, Nüfus Projeksiyonları, 2018-2080, (21 Şubat 2018). 
2017 yılı Adrese Dayalı Nüfus Kayıt Sistemi (ADNKS) sonuçları temel alınarak, biri ana senaryo olmak üzere üç farklı doğurganlık ve göç varsayımlarını içeren üç ayrı senaryoya göre nüfus projeksiyonları üretilmiştir. Demografik göstergelerdeki mevcut eğilimler devam ettiği takdirde, 2017 yılı ADNKS sonuçlarına göre 80 milyon 810 bin 525 kişi olan Türkiye nüfusunun, 2023 yılında 86 milyon 907 bin 367 kişiye; 2040 yılında ise 100 milyon 331 bin 233 kişiye ulaşması beklenmektedir. Nüfusun 2069 yılına kadar artarak 107 milyon 664 bin 79 kişiyle en yüksek değerine ulaşacaktır. Bu yıldan itibaren azalışa geçmesi öngörülen ülke nüfusu 2080 yılında 107 milyon 100 bin 904 kişi olacaktır (Bkz. Tablo 6). Ülkemizde doğuştan beklenen yaşam süresi artmakta ve nüfusumuz yaşlanmaya devam etmektedir. Nüfusun yaş yapısının önemli bir göstergesi olan ortanca yaşın 2018 yılında 32; 2023'te 33,5; 2040' da 38,5; 2060' da 42,3; 2080'de ise 45 olması beklenmektedir. Yaşlı nüfus olarak tanımlanan 65 yaş ve üzerindeki nüfusun oranının 2018 yllında \%8,7; 2023'te \%10,2; 2040'da \%16,3; 2060'ta \%22,6 ve 2080'de \%25,6 olacağ 1 öngörülmektedir.

Tablo 6. Yıllara ve Yaş Gruplarına Göre Nüfus, 2018, 2023, 2040, 2060, 2080.

\begin{tabular}{lrrrrrrrr}
\hline & & & & & \multicolumn{3}{c}{ Oran (\%) } \\
\cline { 7 - 9 } Yll & Toplam & $0-14$ & $15-64$ & $65+$ & $0-14$ & $15-64$ & $65+$ \\
\hline 2018 & $\mathbf{8 1 8 6 7 2 2 3}$ & 19203792 & 55500077 & 7163354 & 23,5 & 67,8 & 8,7 \\
2023 & $\mathbf{8 6 9 0 7 3 6 7}$ & 19601384 & 58438033 & 8867951 & 22,6 & 67,2 & 10,2 \\
2040 & $\mathbf{1 0 0 3 3 1 2 3 3}$ & 19333893 & 64623369 & 16373971 & 19,3 & 64,4 & 16,3 \\
2060 & $\mathbf{1 0 7 0 9 5 9 9 8}$ & 18126086 & 64727126 & 24242787 & 16,9 & 60,4 & 22,6 \\
2080 & $\mathbf{1 0 7 1 0 0 9 0 4}$ & 16813783 & 62873761 & 27413359 & 15,7 & 58,7 & 25,6 \\
\hline
\end{tabular}

Kaynak: TÜIKK, Haber Bülteni, Nüfus Projeksiyonları, 2018-2080, (21 Şubat 2018).

\section{SOSYAL SORUN OLARAK YAŞLILIK}

Yakın zamana kadar yaşlılık, insan yaşamının doğal bir dönemi olarak nitelendirilmekte ve sağlıklı olan her bireyin kolaylıkla deneyimleyebileceği ve erişebileceği bir dönem olarak kabul edilmekle birlikte, günümüzde yaşlılık herkesin erişmeyi hayal ettiği ve ancak ayrıcalıklı insanların erişebileceği önemli bir değer olarak kabul edilmektedir. Teknoloji ve sağlık alanında yaşanan bilimsel gelişmeler ve buna bağlı olarak ortalama yaşam süresindeki artış, yaşlılığ sorunlarla anılan bir yaşam dönemi haline getirmiştir. Sosyoekonomik yaşamda meydana gelen değişimler yaşlılığı bir değer olmanın ötesine çıararak bir sorun dönemi olarak algılanmasına neden olmuştur (Ceylan, 2015: 25-26). Yaşlıların yaşadığı sorun alanlarını dört temel başlık altında toplamak mümkündür. Bunlar; sosyo-kültürel sorunlar, ekonomik sorunlar, psikolojik ve biyolojik sorunlardır. Bu dönemde bireyler, barınma, gelir, ulaşım, ev ve aile ile olan ilişkiler, sosyal ilişkiler vb. alanlarda sorunlar yaşamaktadır. Bu sorunların oluşmasındaki temel faktörler ise, aile yapısındaki değişim, emeklilik, konut edinme sorunu ve teknoloji ile uyum olarak siralanabilir.

Tüm bu sorunlar içerisinde, yaşlılıkla birlikte bireysel yaşamda meydana gelen değişimlerin yarattığı sorunları sosyo-kültürel sorunlar olarak tanımlamak mümkündür. Bunlardan birkaçını yalnızlık, kent yaşamına uyum sağlayamama, rol ve statü kaybı, kuşaklar arası çatışma vb. olarak sıralamak mümkündür (Arpac1, 2005: 120). 
Yaşl1lı̆ı̆ bilgelik, tecrübe ve erdem olarak değerlendirildiği düşünce yapısından; bir yük, yetersizlik, başkasına bağımlılık olarak değerlendirildiği düşünce yapısına geçiş toplumda bireylerin yaşlı algısının da değiştiğinin açık bir göstergesidir. Ortalama yaşam süresindeki artış, kaba doğum ve ölüm oranlarındaki azalmalar ile yaşlıların toplam nüfus içerisindeki paylarının büyümesi gibi demografik değişimler, yaşlıllğın sosyal bir sorun olarak algılanmasında temel itici unsurlar olmuştur (Arpac1, 2005: 25; Ceylan, 2015: 41). Geleneksel toplum yapisında, bilgeliğin ve tecrübenin temsili olarak değerlendirilen yaşlılık; toplumların modernleşmesiyle birlikte bir kambur ve yük olarak değerlendirilmeye başlanmıştır. Bunda, değişen aile yapısı, kadının toplumsal ve sınıfsal konumundaki değişim, kentlileşme vb. unsurların payı büyüktür.

Yaşlılı̆̆ın bir sorun olarak algılanmasının bir diğer nedeni ise, yaşlıların değersiz ve işe yaramaz olarak algılanmaya başlanmasıdır. Yaşlılık ekonomik bir sorun olarak da algılanabilmektedir. Bunun temel nedeni ise çalışmanın ve üretmenin temel bir sorumluluk olarak değerlendirilerek yaşamın merkezine koyulmuş olmasıdır. Yaşlılıkla birlikte bireylerin daha az üretiyor olması ya da hiç üretmiyor olması, yaşlıların işe yaramaz ve değersiz olarak algılanmaları; yaşlıların ticari faaliyet içerisinde bulunmamaları ve ekonomik sistem içerisinde sürekli tüketen taraf olarak değerlendirilmeleri toplum içerisinde "kambur" olarak nitelendirilmelerine neden olmaktadır (Ceylan, 2015: 44; Kalınkara, 2011: 69; Çilingiroğlu ve Demirel, 2004: 228). Bunlara ilave olarak, yaşlılığı ya da yaşlı bireylerin tamamı için aynı olumsuz ifadeleri kullanmak doğru olmayacaktır. Yaşlı nüfus içerisinde olmasına rağmen halen üretmeye ve yaşam içerisinde her alanda mücadeleye devam etmekte olan yaşlılar da bulunmaktadır. Bu bağlamda yaşlılıkla birlikte, aile ve çevre ilişkilerinin zayıflaması, kendilerini yaşlı hisseden bireylerin sayısının artmasına neden olmaktadır (Arpac1, 2005: 120).

Çalışmanın başında da belirtildiği üzere, günümüzde nüfusun yaşlanma eğilimi içerisine girmesi ve mevcut durumun öncelikle ülke sosyal güvenlik sistemi üzerinde yük oluşturmaya başlayacağı (bozulan aktif-pasif sigortalı dengesi, sağlık sigortası kapsamı, yaşlılık aylığı ödeme süresi vb.) düşüncesi yaşlılığın bir sorun olarak ortaya çıkmasında bir diğer belirleyen olmuştur. Yaşlılığın, bir sorun olarak algılanmasında toplumsal yapıda, ekonomik yapıda meydana gelen değişim sonrasında, yaşanan değişimin rolü de büyüktür.

Bir önceki paragrafta belirtildiği üzere yaşlılık nedeniyle sağlık harcamalarının artması ve emeklilik ya da üretime katılamama nedeniyle gelirin yetersiz kalması sosyal güvenlik sistemi üzerindeki yükü artırmaktadır. Nüfus içerisinde yaşlı nüfusun artışı, yaşlılara uygulanacak sosyal yardım ve hizmetlerin finansmanın nasıl sağlanacağı noktasında sorun oluşturmakta ve önemli bir finansman kaynağı olan vergi oranlarının artmasına neden olmaktadır. Vergi oranlarındaki artış aynı zamanda sermaye, yatırım ve işgücünü de olumsuz yönde etkileyerek; yatırımların ve işgücünün dışarıya taşınmasına, işsizliğin artmasına ve vergi gelirlerinin de azalmasına neden olmaktadır (Ceylan, 2015: 43).

Yaşlılık kimi zaman psikolojik bir sorun olarak da değerlendirilmektedir. Bireylerin yaşlılıkla birlikte fiziksel görünümünde yaşanan değişimler, yaşlı bireylerin sosyal yaşama katılmaları ve diğer bireylerle ilişki kurmaları noktasında sorun oluşturmaktadır.

Yaşlılığın sosyal bir sorun olarak algilanmasının bir diğer nedenini de teknolojik gelişmeler oluşturabilir. Bilginin üretilmesinin ve oluşturulmasının daha da fazla önem kazanmaya başladığı günümüz bilgi toplumunda, teknoloji çoğunlukla genç bireyler tarafından kullanılmakta ve geliştirilmektedir. Sadece çalışma hayatı içerisinde değil günlük yaşamsal ihtiyaçların karşılanması noktasında da teknolojiye duyulan ihtiyacın her geçen gün artıyor olması; bilgiyi, erdemi ve tecrübeyi elinde bulunduran yaşlılara duyulan ihtiyacın da azalmasına; ayrıca teknolojiye uyum sorunu yaşlıların toplum içerisindeki saygınlığının da kaybolmasına neden olmaktadir. 
Genel olarak ifade etmek gerekirse yaşlılık kavramı hangi yönüyle ele alınmış olursa olsun, biyolojik, sosyolojik, fonksiyonel ya da psikolojik, yaş ilerledikçe yukarıda ana hatlarıyla ifade edilmeye çalışılan sorunların ortaya çıkması, yaşlı nüfusun istihdamını da zorlaştırmaktadır. Özellikle yaşlılara yönelik sosyal yardım, sosyal hizmet ve sosyal korumanın yetersiz olduğu ülkelerde yaşlı nüfusun çalışma yaşamından uzak kalması, yoksulluğun 65 yaş üzeri nüfusu daha fazla etkiliyor olması, yaşlıların yaşadıkları toplumun her alanından uzaklaşmaya başlamasına neden olmaktadır. Bu bağlamda sosyal sorun olarak yaşlılığın tanınması ve uygun çözüm arayışlarında bulunulması önem taşımaktadır. Bu çözümlerden en öncelikli olanı ise eğitimdir. Çünkü yaşlılar, kaliteli bir yaşam ve sağlığa ihtiyaç duyan ve sosyal açıdan savunmasız bireylerdir. Ayrıca, yukarıda sıralanmaya çalışılan sorun alanları kapsamında, eğitim, sağlık hizmetleri, mesleki eğitim ve yaşlıların yeniden eğitilmesi (ileri yaş eğitimi) gibi sosyal hizmetlerin geliştirilmesine giderek daha fazla ihtiyaç duyulmaktadır (Bekisheva vd., 2017: 67).

\section{YAŞLILARIN SOSYO-EKONOMIK HAYATA UYUM SORUNU VE İLERI YAŞ EĞTIMININ ÖNEMİ}

Yaşlı bireylerin yaşamaya ve yaşama dair (sağlık, güvenlik, barınma, beslenme, sosyo-ekonomik katılım vb.) bazı ihtiyaçlarının karşılanması ihtiyacı, dünyada sadece gelişmiş ülkelerde değil Türkiye gibi gelişmekte olan ülkelerde de ekonomik, sosyal ve kültürel bir sorun olarak giderek önemini artırmaktadır. Ülkelerin sahip oldukları ekonomik, sosyal, siyasal ve kültürel yapılardaki farklılıklar; yaşlılık sorununa bakışı da çeşitlendirmek ve yaşlılık daha öncede belirtildiği üzere farklı disiplinlerin ilgilendiği bir olgu olmuştur (Sabancı ve Howe, 2009: 10).

Gelişmiş ülkelerin nüfusun yaşlanması sorunu ile aniden değil kademeli olarak karşılaşacakları; gelişmekte olan ülkelerin ise ani olarak karşılaşacakları öngörülmektedir. Arun'un (2008) çalışmasında elde ettiği sonuçlara göre Avrupa ülkelerinin (Fransa ve İşviçre gibi) yaklaşık 100 yılda geçirdiği yaşlanma sürecini Türkiye' nin 15-20 yılda geçireceği tahmin edilmektedir (Arun, 2008: 314).

Dünya nüfusunun yaşlanmasıyla birlikte, günümüzde yaşlılıkla ilgili sorunlarla daha fazla karşılaşılır olunmuştur. Yaşlılık dönemine dair sorunların bazıları yaşlı bireylerin kendisinden kaynaklanırken (fiziksel, psikolojik ve ekonomik); bazıları ise dışsal faktörlerle (çevresel koşullar) ilgilidir. Bu bağlamda, yukarıda da ifade edildiği üzere, yaşlılık bireysel bir sorun olmaktan çok toplumsal bir sorundur ve yaşlı bireyin yaşadığı ülkenin ekonomik, sosyal ve kültürel politika ve uygulamalarından doğrudan etkilenmektedir. Bu bağlamda ülkelerin sosyal güvenlik ve sosyal politika alanında uyguladığı politikaların yaşlılığa dair sorunların azaltılmasında ya da artırılmasında etkisi büyüktür (Kurt vd., 2010: 34).

Ortalama yaşam süresinin uzaması birey açısından olumlu bir değer olarak nitelendirilebilir. Ancak yaşam süresinin uzamasıyla birlikte yaşlının bir başka bireye bağımlılığının ya da ülke genelinde yaşlı nüfustaki artışla birlikte toplum üzerindeki bağımlılık yükünün artması olumsuzlukları da beraberinde getirmektedir (Boran ve Kurnaz, 2019: 39). Yaşlı nüfusun emeklilik döneminde emek piyasasından uzaklaşması, ekonomik anlamda üretime katkısı olmamakla birlikte tüketici olarak ekonomik sistem içerisinde varlığının devam etmesi, toplum üzerinde bir yük olarak anlaşılmasının önemli bir nedenidir. Toplumun ekonomik ve sosyal yapısındaki değişim ile birlikte yaşlı nüfustan beklenen rol ve sorumluluklar da farklılaşmıştır. Yaşlı nüfusun tarıma dayalı geleneksel toplum yapısında özellikle emeklilik sonrası dönemde bilgisine ve tecrübesine ihtiyaç duyulan bireyler olarak anılması; modern dönemle birlikte toplum içerisinde anlamını yitirdiği gözlenmektedir (Ceylan, 2015: 26). 
Yaşlı bireyler çok fazla kronik hastalık ve sağlık sorunu yaşamakla birlikte; yaşlılık döneminde kuşkusuz karşılaşılan önemli diğer sorun ise sosyal ve ekonomik sorunlardır. Emeklilik ya da aileyi geçindiren bireyin ölümü sonrası yaşanılan geçim sıkıntısı yaşlı bireylerin karşı karşıya kaldıkları en temel ekonomik sorundur. Emeklilikle elde edilen gelirin hissedilir düzeyde azalması ya da ölüm sonrasında almaya hak kazanılan ölüm aylıklarının azlığı yaşlı bireylerin kendi geçimlerini sağlamalarını güçleştirmektedir. Çetin (2019)'in, 55 yaş ve üzeri yaş grubundaki emekli ya da emekli olması çok yakın olan 20 mavi ve beyaz yakalı kişi üzerinden gerçekleştirdiği nitel araştırma sonuçlarına göre, emeklilik sonrası yaşanılacak gelir azalması görüşmeye katılanlarca bir sorun olarak değerlendirilmiş ve emekliliğin yaşlılık olarak algılandığı sonucuna ulaşılmıştır (Çetin, 2019: 29). Bu bağlamda başkalarına sadece bakım ve koruma anlamında değil ekonomik olarak da bağımlılık doğmakta ve yoksulluk temel bir yaşlılık sorunu haline gelmektedir. Yaşlı bireylerin içinde bulundukları ülkelerin ekonomik durumları da bu sorunun yaşanmasında belirleyicidir. Gelişmişlik düzeyi artıkça yaşlı bireylerin ekonomik sorun yaşama sıklıkları da azalmaktadır. Tufan vd. (2019), Türkiye özelinde gerçekleştirdikleri panel veri analizinde, sorunu destekler bulgular elde etmiştir. Buna göre, yaşlilıkla birlikte yaşanılan gelir kaybı, özellikle de kadınlar için, yoksulluk yaşlılık döneminde karşılaşılan önemli sorundur. Benzer bir sonuç Ak ve Közleme (2017)'nin Gaziantep ili özelinde yaptıkları çalışmalarında da elde edilmiş ve yaşlılık döneminde bireylerin daha sık ekonomik güçlük ve yoksulluk sorunu ile karşılaştıkları belirtilmiştir.

Yaşlı bireylerin yaşadıkları bir diğer önemli sorun alanı ise sosyal uyumdur. Yaşlılık döneminde bireylerin aile ve sosyal ilişkileri ve toplumla olan uyumları da olumsuz yönde etkilenmektedir. Yaşlı bireylerin eğitim düzeyleri, meslekleri, gelir durumu ve çevresel faktörler sosyal uyumda etkili olmaktadır (Kurt vd., 2010: 34). Yaşlılıkla birlikte aile bireylerinden ve arkadaşlardan uzaklaşma yaşlı bireylerin yalnızlığı sorunun yaratmaktadır. Yaş ilerledikçe aile bireylerinden çok arkadaşlara olan ihtiyaç artmakta ve arkadaşların varlığı sosyal uyum için önemli hale gelmektedir. Ardahan vd. (2007), çalışmalarında yalnızlıkla mücadelede arkadaş desteğinin ne kadar önemli olduğunu vurgulamıştır (Ardahan vd., 2007: 126). Bu bağlamda eğitim amaciyla yaşlı bireylerin bir araya gelmeleri yeni arkadaşlıkların kazanılması ve sosyal uyumun sağlanması anlamında da büyük öneme sahip olacaktır.

Uzun süren çalışma hayatı sonrasında yaşlı bireyler emeklilik ile birlikte hem çalışma ortamlarından hem de çalışma hayatının kendilerine kazandırdığı sosyal ve kültürel çevreden uzaklaşmaktadır. Yaşlı bireylerin gerek çalışılan çevreden gerekse de sosyal ve kültürel çevreden uzaklaşması beraberinde geçim sıkıntısı ve yoksulluk dışında sosyal dışlanma ve topluma uyum sağlama noktasında sorunlar da getirmektedir. Toplumsal yapıda meydana gelen hızlı değişim yaşlı bireylerin sosyal uyum sorunlarının daha derin yaşanmasına neden olmaktadır. Buna ek olarak emeklilik dönemi ile birlikte boş zaman miktarı artmış olsa bile emeklilik, yaşlı bireylerin mevcut boş zamanı değerlendirilmesini de sorun haline getirmektedir. Boş zamanın çokluğu yaşlı bireyleri kendini dinleme, kuruntuya kapılma ya da düşünerek kendilerini sıkıntıya itmelerine neden olmaktadır. Çetin (2019), çalışmasında işgücü piyasasında beyaz yakalı olarak çalışan bireylerin, mavi yakalı çalışanlardan farklı olarak, emeklilik sonrasında serbest zaman değerlendirmede eğitime ağırlık verdikleri sonucuna ulaşmıştır. Buna göre, beyaz yakalı çalışanlar emeklilik sonrası dönemde sosyal uyum amacıyla yeni şeyler öğrenmeye yönelik eğilimlerinin yüksek olduğunu belirtmiştir (Çetin, 2019: 27).

Yaşlılığı sosyal yaşamda yaşanılan eksiklik ve yoksunlukların bir sonucu olarak değerlendiren sosyal alan teorileri bu sorunu açılamada önemlidir. Sosyal alan teorilerinden özellikle ilgisizlik, aktivite, süreklilik ve alışveriş teorileriyle açıklanmaya çalışılan yaşlılık kavramı ve algısı yaşlıların neden sosyo-ekonomik hayata uyumda bazı sorunlar yaşadıklarını betimler niteliktedir. Literatürde yer alan tanımlamalar ve çalışmalar göstermektedir ki; bireylerin 
yaşlanma dönemlerindeki deneyimleri arasında büyük farklılıklar bulunmaktadır. Bunun nedeni her bir yaşlının farklı yaşam deneyimlerinin ve tarzlarının olmasıyla ilişkilendirilebilir. Bu bağlamda yaşlılık döneminde sağlik, fiziksel yeterlilik, zihinsel aktiflik ve toplumsal uyum açısından bireyler arasında farklılıklar bulunmaktadır (Görgün- Baran ve Kurnaz, 2019: 40). 21. yüzyıl ile birlikte yaşlanma, toplumsal koşullardaki değişim ile birlikte geçmiş yıllardaki yaşlanma süreçlerinden farklılık göstermektedir. Toplumsal bir sorun olarak nitelendirilen yaşlılık sorunu ile mücadele edebilmede yaşlı bireylerin sorunlarını çözebilmek için çeşitli politikalar üretilmekte ancak bu politikalar sorunların çözümünde yetersiz kalmaktadır. Bu bağlamda hem toplumun yaşlılık sorunu ile mücadele edebilmesini sağlayacak hem de yaşlı bireylerin bireysel sorunlarına çözüm olabilecek bazı politika arayışlarına girilmiş ve Dünya Sağlık Örgütü tarafından ilk olarak 2002 yılında Aktif Yaşlanma Politika Belgesi'nde "aktif yaşlanma" çözüm önerisinde bulunulmuştur. Belgede aktif yaşlanma; "yaşam süresi uzadıkça insanların yaşam kalitesini yükseltmek için sağlık, katılım ve güvenlik firsatlarının en iyi duruma getirilme süreci" olarak tanımlanmaktadır. Bu bağlamda aktif yaşlanma bireylere sadece ihtiyaç duyduklarında yeterli koruma, güvenlik ve bakım hizmetleri sunmakla yetinmemekte aynı zamanda yaşamlarını refah içerisinde sürdürebilmeleri için kendi potansiyellerini gerçekleştirme ve ihtiyaç, istek ve yapabilirlikleri doğrultusunda topluma katılabilmelerine olanak tanımaktadır (Canatan ve Boz, 2019: 350). Bu bağlamda, Narushima (2008)'nın da çalışmasında elde ettiği bulgulara göre de ileri yaş döneminde devam eden eğitim ya da bir diğer ifadeyle yaşam boyu eğitim özellikle metropol yaşamı içerisinde yaşlıların sosyal uyum sorununu ve dezavantajlı olma riskini azaltmaktadır (Narushima, 2008: 681).

Aktif yaşlanma bağlamında yaşlı bireylerin belirlenen hedefler doğrultusunda topluma katılabilmeleri ve uyumu eğitim ile mümkün olacaktır. Bu nedenle Dünya genelinde nüfusta yaşanılan demografik değişiklikler, yaşlılara yönelik politikaları yeniden değerlendirme yönünde büyük oranda etki etmektedir. Çoğu zaman yaşlı bireyler emeklilik sonrası dönemde devletin yaşlılara yönelik politikalarını sorgulamakta ve sadece ekonomik özgürlük, bakım ve koruma noktasında sağlanan politikaların ötesinde sosyo-ekonomik hayata uyumda farklı eğitim olanakları sunulmasında ısrarcı davranmaktadır (Githens, 2007: 1). Bu bağlamda yaşlıların bakım ve korunmasına ilişkin politika uygulamaları tek başına yeterli görülmemekte; yaşlıların sosyoekonomik hayata uyumlarının sağlanması yönündeki politika uygulamalarının daha başarılı olacağı öngörülebilmektedir (Korkmaz ve Korkut, 2018: 267). İleri yaş eğitimi bu anlamda büyük önem taşımaktadır. Aktif yaşlanma sürecinde ileri yaş eğitimi temel olarak bireylerin yaşlılıkta toplum içerisinde aktif olmasını ve rollerine devam etmesini amaçlamaktadır (Canatan ve Boz, 2019: 350). Bu eğitim, yaşlı bireylerin eğitim düzeylerini geliştirerek yaşam kalitelerini arttırmalarına yardımcı olacaktır. Duman (2000) yılındaki çalışmasında ileri yaş eğitiminin amaçların1; "toplumun gereksinim duyduğu bilgi, görgü, beceri ve yeterlik düzeyine sahip bir yetişkinler toplumu oluşturmak; yaşl bireylerin içinde yaşadıkları toplumun gelişmesini ve yaşamasını engelleyen sorunların üstesinden gelmeye ilgili bir anlayış geliştirmek ve bireyleri bu sorunların çözümüne hazırlamak ve yaşlı bireylere kendi tutum, bilgi, anlayış ve özelliklerini geliştirme fırsat ve olanakları sağlamak" olarak sıralamaktadır (Duman, 200: 43). İlave olarak yaşam bilincinin geliştirilmesi ve toplumsal değişime uyum sağlanması da temel amaçlar olarak sıralanabilir (Yazar, 2012: 22-23). Kontaş (2007), genç yaşlarda elde edilen eğitim fırsatları, yaşlılık döneminde elde edilen ileri yaş eğitim fırsatlarıyla birleştiğinde yaşlı bireylerin ileri yaşlarda bağımsızlıklarını koruma ve yeni durumlara uyum sağlama konusunda yardımcı olacağını ileri sürmektedir. Diğer bir çalışmada Gülseren ve arkadaşları (2000) eğitim düzeyi ile birçok bilişsel işlev arasında pozitif yönlü bir ilişki olduğunu ortaya koymuştur (Sabancı ve Howe, 2009: 12).

Bergevin (1967)'e göre, ileri yaş eğitimi temel felsefi bazı değer ve kuramlara dayanmaktadır. Bunlar; yaşlı bireylere yaşamdan zevk almaları için yardımcı olmak; yaşlı bireylere iletişim 
kurmaları, yeteneklerini keşfetmeleri ve anlamaları için yardımcı olmak; ileri yaş eğitiminin yararını ve gerekliliğini anlatmak; yaşlı bireylerin mesleki, politik, bedensel, kültürel vb. alanlardaki gelişimlerine yardımcı olacak koşulları hazırlamak ile sağlık ve sosyal alanlarda düzeylerine uygun sürekli bir eğitim sağlamak olarak sıralanmaktadır (Yazar, 2012: 23).

Yaşam beklentisi ile eğitim düzeyi ve eğitime katılım düzeyi arasında doğrudan bir bağlantı olduğu tahmin edilmektedir. Yaşlı bireylerin eğitim sayesinde bilgilerinin güncel kalması doğrudan yaşam tarzlarını ve hastalıklara karşı tutumlarını olumlu yönde etkilemektedir. Sosyal öğrenme olarak tanımlanan bu öğrenme modeli yaşlı bireylerin toplum içerisindeki aktif konumunu koruyarak kişisel gelişimlerini ve sosyo-ekonomik yaşama uyumlarını sağlama noktasında önem taşımaktadır (Bekisheva vd., 2016: 67). Canatan ve Boz (2019), Ankara ili özelinde yaptıkları çalışmalarında yaşlıların eğitim verilen kurs ve etkinliklere katılarak yeni arkadaşlıklar edindikleri, sosyalleşme imkanı buldukları, insan içine çıkma cesareti kazandıklarını ve kendilerini eve bağlı hissetmediklerine dair bulgular elde etmişlerdir (Canatan ve Boz, 2019: 355). Görgün-Baran (2008)'de çalışmalarında benzer bir sonuca ulaşmışlar ve yaşlılık döneminde öğrenme süreci devam ettiği için sosyalleşmenin de yaşam boyu devam ettiğini ifade etmişlerdir (Görgün-Baran, 2008: 89).

Günümüzde "emeklilik" kavramı yerini "modern emeklilik" kavramına bırakmıştır. İşten tamamen ayrılma ile başlayan emeklilik, sosyo-ekonomik hayata dair yapılabileceklerin sonu olarak değerlendirilmez olmuştur. Ortalama yaşam süresindeki artış ile birlikte yaşlı bireyler emeklilik sonrasında ücretli ya da ücretsiz, tam ya da yarı zamanlı, esnek ya da geçici olsun istihdam içerisinde olmak ve istihdamın kendilerine sağlayacağ ekonomik, sosyal ve psikolojik yararlarından faydalanmak istemektedir (Hale, 1990: 917; Stein, Rocco ve Goldenetz, 2000: 62). İstihdam içerisinde yer alma isteği sadece yaşlı bireylerin tercihi değil, aynı zamanda işletmeler ve işverenler de deneyimli personel sayısındaki azalma ve deneyimli personele duyulan ihtiyaç noktasında istekli davranmaktadır (Ennis-Cole ve Allen, 1998: 37). Emeğini arz etmek isteyenler ve emek talep edenler bağlamında söz edilen bu iki tespit emek piyasasında emeklilik dönemi algısının farklılaştı̆̆ının önemli bir göstergesidir (Stein ve Rocco, 2001: 2-5). Bu nedenle emeklilik sonrası dönemde yaşlı bireylerin emek piyasasının gereklerini takip edebildikleri ve çalışma hayatında kalma sorunlarını en aza indirebilmelerinde ileri yaş eğitimi önemlidir. Özetle emeklilik döneminde yaşlı bireyler eğitimlerine devam etmek istemektedir.

Bir başkasına bağlı olmaksızın iletişim kurabilme, yeni bilgiler edine bilme isteği ile yaşamlarının kendilerince zor dönemlerinde stresten uzak kalma düşüncesi ve yeteneklerini keşfetme dürtüsü eğitim isteğinin diğer belirleyicileridir (Bekisheva vd., 2016: 67). Bu bağlamda, eğitim yaşlı bireylerin hem yeni sosyal yaşam hem de çalışma yaşamı koşullarına uyum sağlama yeteneğini geliştirmeye yardımcı olmaktadır. Yerel düzeydeki kurslara katılım sağlayan 60 yaş ve üzeri yaş grubundaki bireyler üzerine yaptıkları araştırmalarında Narushima, Liu ve Diestelkamp (2016), yaşlılık döneminde alınan eğitimin bireylerin yeteneklerini keşfetmelerine, kendi öz saygınlıklarını yeniden kazanmalarına ve iyilik hallerinin sürekliliğine katkı sağladığı sonucuna ulaşmışlardır (Narushima, Liu ve Diestelkamp, 2016: 651).

İleri yaş eğitimi, yaşlı bireylerin var olan yeteneklerini geliştirmelerine ya da yeni beceriler kazanmalarına yardımcı olabileceği gibi bireylerin bilgilerini artırmalarına, teknik veya mesleki yeterliliklerini iyileştirmelerine ve geliştirmelerini de sağlayacaktır. Ayrıca ileri yaş eğitimi, yaşlı bireylerin şu an karşı karşıya kaldıkları bazı sorunları çözüme kavuşturmalarında da fayda sağlayacaktır (Yazar, 2012: 22).

Yaşlı bireylerin sosyo-ekonomik hayata katılımlarına, emek piyasası bağlamında, farklı kaynaklar yardımcı olmaktadır. Bunlar; ücretli olarak çalışma, gönüllü görevlerde yer alma ve eğitim fırsatlarından yararlanma olarak sıralanabilir. Bu bağlamda, esnek çalışma modelleri yaşlı 
bireyler için önemli bir fırsat olarak değerlendirilebilir. ABD'de özel bir finansal hizmet sağlık şirketi çağrı merkezi, temsilci olarak evde oturan yaşlı bireylerin kullanımının faydalı olduğunu ifade etmektedir. Çünkü sigorta ve finansman şirketi müşterileri kendilerinden yaşça büyük olan bir çalışanın ilgili alanda verdikleri bilgilerin ve deneyim paylaşımlarının daha kıymetli olduğunu bildirmektedir (Dychwald, Erickson ve Morison, 2004: 48-57). Yine ABD'de bir başka çağrı merkezi üzerinden gerçekleştirilen araştırmada da yaşlı çalışanların müşterileriyle telefonda daha uzun vakit geçirdikleri ve yaşlı çalışanların görüşmelerinin genç çalışanların görüşmelerinden daha olumlu ve iyi sonuçlandığı bilgisi elde edilmiştir (Githens, 2007: 2). Her iki örnek bize göstermektedir $\mathrm{ki}$, işletmelerin bunlar gibi yeni istihdam alanlarını deneyimlemeleri hem yaşlı bireylerin ihtiyaçlarına uygun bir ortamda çalışma fırsatı bulmalarına hem de işverenlerin deneyimli çalışanlardan yararlanmalarına imkan sağlamaktadır. Esnek çalışma modellerinin yaşlı bireylerce tercih edilmesinde teknoloji bilgisinin aktarımı büyük önem taşımaktadır. $\mathrm{Bu}$ nedenle sahip olunan tecrübe ile teknolojik bilginin etkin biçimde kullanılabilmesi için yaşlı bireylerin eğitimi önem taşımaktadır.

Nicholas (2001)'ın Amerika'da altı farklı işletme özelinde gerçekleştirdiği çalışmasında işverenler ile yaşlı çalışanlar arasındaki ilişki yönetimi betimlenmeye çalışılmıştır. Çalışmada elde edilen bulgulardan ilki her bir yaşlı çalışanın farklı karakter özelliklerine sahip oldukları ve yönetimlerinin de farklılık gösterdiği noktasındadır. Yaşlı bireyler arasında fiziksel sağlık durumları, teknolojiye uyum sağlama, eğitim ve örgütsel değişimlere açık olma bakımından farklılıklar; aynı yaş grubundaki yaşlı bireylerin benzer yaşam biçim ve tarzlarını varlı̆̆ı ve bazı bakım alanları için başka bireylere ihtiyaç duymaları bakımından da benzerlikler bulunmaktadır (Githens, 2007: 3).

Bunlara ilave olarak yaşlı bireylerle ilgili olarak vurgulanması gereken bir başka durum ise, öğrenmeye karşı katı olmaları ve öğrenemeye karşı direnmeleri ile ilgili toplumsal önyargıdır. Yaşlı bireylerle ilgili önyargıların olumsuzluğu yaşlı bireylerin çalışma performanslarını olumsuz yönde etkilerken; olumlu düşünceler ise performanslarını da olumlu yönde etkilemektedir. Ancak bilinen odur ki, katılık yaşın bir unsuru ya da sonucu değildir; bireysel yaşanmışlıklar, baskı ve yatkınlıkların bir sonucudur. Yaşlı bireylerin eğitimden uzak kalmaları ise çoğu zaman hafıza kayıplarını diğer bireylerin fark etmesinden duydukları çekincedir. Yaşlı bireylere uygun yeterli eğitim alanının bulunmaması bunda etkendir.

Çalışma yaşamındaki eğitim ve gelişim programların çoğunluğu genç çalışanlara yönelik olduğu görülmektedir. Rizzuto ve Mohammed (2005)'in gerçekleştirdiği çalışma elde edilen bulgularda bu sonucu destekler niteliktedir. Çalışmada ABD'nin Pensilvanya eyaletindeki birçok devlet kurumu incelenmiş ve yaşlı çalışanların beklenenin aksine değişime çok da dirençli olmadıkları, hatta yaşça büyük ve kıdemli çalışanların genç ve yeni çalışanlardan öğrenme konusunda daha istekli olduklarını sonucuna ulaşılmıştır. Çalışmada elde edilen bir başka sonuç ise, yaşlı çalışanların öğrenmede genç çalışanlar gibi hızlı olmasalar bile örgüt içerisindeki değişimleri daha olumlu kabul ettikleri ve uyum sağladıkları yönündedir (Githens, 2007: 3). Bu sonuçlar göstermektedir ki, yaşlı çalışanların, gençlere göre, öğrenme konusunda daha isteklidirler ve işverenler de yaşlı çalışanların değişime karşı daha katı oldukları yönündeki önyargılarını dikkate almamaları ve yaşlı çalışanların uzmanlıklarından yararlanmaları önem taşımaktadır.

Amerika' da PEW Araştırma Merkezinin, internet ve teknoloji kullanım sıklığına ilişkin yaptıkları araştırmaya göre, 65 yaş ve üzeri yaş grubundaki bireylerin internet kullanımının 56-64 yaş aralığındaki bireylerden daha yüksek olduğunu göstermektedir. Buna ilave olarak günümüzün 56-64 yaş aralığındaki bireylerinin ise gelecekte yaşlanacakları öngörüsü ile çevrimiçi internet kullanımının daha da fazla artacağı tahmin edilmektedir (https://www.pewresearch.org). Yaşlı bireylerin bilgisayar kullanmayı istemelerindeki temel amaçlardan ilki, bugünün modern yaşamı ile temas halinde olma isteği iken; diğer amaç ise soyağaçlarına ilişkin projeler üzerinde çalışma 
ve aile ile iletişim kurma isteğidir (White ve Weatheall, 2000: 376-377). Lipphardt vd., (2017)'ın yetişkinlerin teknoloji kullanım nedenleri ile ilgili olarak 187 katılımcı üzerinden yaptıkları çalışmaya göre, yaşlı bireyler bilgi toplumuna katılma ve genç nesillere uyum sağlama amacıyla internet kullanımını öğrenmenin önemli olduğunu ifade etmektedir (Lipphardt vd., 2017: 956). İnternet ve bilgisayar kullanımına yönelik eğitim ve uygulamalar yaşlı bireylerin çalışma ve yoksulluk sorunun çözümünde etkilidir.

Yaşlı bireylerin ileri yaş eğitim sürecine katılımı, toplumdan uzaklaşmaları, sosyal anlamda dışlanmaları sorunlarına çözüm oluşturmakla birlikte, kültür ve geleneklerin nesiller arasında aktarımının sağlanmasına da yardımcı olmaktadır. Doğru (2019), gençlerin yaşlılık ve evde bakım konusundaki algılarını ölçmeyi amaçladığı çalışmasında, yaşlı bireylerin sadece kendi yaşıtları ya da aktanlarıyla değil genç nesil ile de iletişim halinde olmalarının hem yaşlı bireylerin yaşlılık dönemlerinin daha olumlu geçmesine hem de genç nesillerin bilinç düzeylerinin gelişmesine katkı sağlayacağını vurgulamaktadır (Doğru, 2019: 1). Özmete (2017)'e göre de nesiller arası iletişim söz konusu olduğunda yaşlı bireyler geçmiş ile gelecek arasında bir bağ olurlar. Bu bağlamda yaşlı bireyler toplumun değerler ve yaşanmışlıklar anlamında sürekliliğin sağlanmasında önemli bir kilit taşıdır (Özmete, 2017: 5). Bu bakış açısıyla ileri yaş eğitimi ile yaşlı bireylerin genç bireylerle bir araya gelmeleri hem yaşlı bireylerin hem de genç bireylerin sosyal uyum sorunlarını ve kuşak çatışmalarını çözümlemelerini sağlayacak hem de sosyal dışlanma ve ayrımcılık sorununa karşılık bireysel ve toplumsal bir fayda sağlayacaktır (Toprak ve Erdoğan, 2012: 87).

Gelişen günün koşullarına göre, bireyin üretkenliğinin ve uyumunun devamlılı̆̆ının sağlanabilmesi için ileri yaş eğitimi büyük önem taşımaktadır. Öyle ki, bireyler her geçen 10 yılda niteliklerini ve bilgi düzeylerini geliştirmek zorunda kalmakta, mesleki ve yaşama dair konularda eğitime ihtiyaç duymaktadır. Bireyin sahip olduğu mesleki eğitimin alması gereken eğitimin dörtte birini oluşturduğu düşünüldügünde, bireylerin yaşlıllk dönemlerinde de eğitimlerine devam edilmesi zorunluluk olarak değerlendirilmektedir (Ültanır ve Ültanır, 2005: $4-5)$.

\section{SONUÇ VE TARTIŞMA}

Yaşlılık döneminin tanımlanması tarihsel sürece ve toplumların farklı sosyal, ekonomik ve siyasal özelliklerine bağlı olarak değişiklik göstermektedir. Kavramsal anlamında yaşanılan değişim, zamanla toplum içerisinde yaşlı bireylere bakışın da farklılaşmasına neden olmuştur. Ayrıca toplam nüfus içerisinde yaşlı nüfusun ağırlığının her geçen gün artması ve nüfus projeksiyonlarının mevcut durumu destekler nitelikteki sonuçları yaşlı bireylere yönelik etkin, planlı ve en önemlisi sürdürülebilir politikaların geliştirilmesini zorunlu kılmaktadır. Bu politikalardan en önemlisi de eğitimdir. Çetin (2019); Canatan ve Boz (2019); Yazar, (2012); Narushima (2008); Ardahan vd., (2007); Githens (2007) ve Kontaş (2007)'nin de vurguladığ planlı ya da gelişi güzel yapılmış olmasına bakılmaksızın eğitim bireylerin içinde yaşadıkları topluma uyum sağlamalarında anahtar rol oynamaktadır. Öğrenme bireylerin sadece çocukluk ve gençlik dönemleriyle sınırlandırılabilecek bir süreç değildir. Toplumsal yaşam ve çalışma yaşamında bilginin giderek önem kazandığı günümüzde eğitim doğumdan ölüme insan yaşamının her aşamasında bir zorunluluk halini almıştır. Artık insanların çocukluk ve gençlik dönemlerinde öğrendikleri bilgiyi yaşlılık dönemlerinde de geliştirmeleri ve yenilemeleri gerekmektedir. Bu anlamda Görgün ve Baran (2008)'in de belirttiği gibi bireyler için en önemli görevi tüm yaşam boyunca öğrenmeyi öğrenmek oluşturmaktadır.

Ayrıca ileri yaş eğitimi, Lipphordt (2017) ve White ve Weatheall (2000) çalışmalarında vurguladığı gibi toplumun hızla değişen sosyo-ekonomik yapısına olduğu kadar ve teknolojik 
ilerlemeye uyum sağlamada da önemli bir rol üstlenmektedir. İleri yaş eğitimi bireylerin yeteneklerini, amaçlarını, ilgisini ve değerlerini destekleyen; bireyler arasında yaş, meslek ve ikamet ayrımı yapmaksızın her insan için tam ve uyumlu yaşam koşulları yaratmayı amaçlayan bir sosyal öğrenme sürecidir.

Çalışma yaşamında ve sosyal yaşamda yer alan eğitim ve geliştirme programlarına yaşlı bireylerin de katılımının desteklenmesi ve işverenlerin yaşlı bireyleri de eğitim almaları konusunda teşvik etmeleri önemlidir. Bu bağlamda yaşlı bireylerin eğitiminde yerel yöneticilerin desteği büyük önem taşımaktadır. Halkın ihtiyaçlarını en iyi bildiği varsayılan yerel yönetimler tarafından yaşlı bireylere yönelik yürütülen hizmetlere katılımın sağlanması, toplum ve birey açısından karşılıklı fayda sağlanmasında önemlidir ve bunun sonucunda sosyal ve ekonomik uyumun olumlu yönde etkileneceği bir gerçektir.

Yaşlı bireylerin, yaşlılığın yaratmış olduğu kısıtlı olma durumu ve yalnızlıkla mücadele edebilmesinde toplumun ona ihtiyacı olduğunu hissettirecek ve ona doyum sağlayacak bir işle meşgul olmasını sağlamak önemlidir. Bu nedenle ileri yaş eğitimi bireylerin ekonomik ve sosyal yaşama katılımında önemli bir etkiye sahiptir. Yalnızca ekonomik güvence sağlamada değil, Çetin (2019)'in de vurguladığı gibi, aynı zamanda mevcut ekonomik kaynağı ve geliri harcama ve yönetmede yaşlıların akılcı davranabilmeleri adına da ileri yaş eğitimi gereklilik olmaktadır. Böylece yoksulluk yaşlı bireyler için sıklıkla karşılaşılan bir sorun olmaktan uzaklaşacaktır.

İleri yaş eğitimine katılmayı tercih eden yaşlı bireyler hayattan uzaklaşmak ya da kopmadan toplumda aktif olarak yer alarak hem sosyalleşmekte hem de daha sağlıklı ve kaliteli bir yaşam sürmektedirler. Bu bağlamda yaşlı bireyler emeklilik sonrasında toplumdan ve sosyal yaşamdan uzakta kendi alanlarına çekilmek yerine sosyal ve ekonomik yaşam içerisinde yer almaya devam etmektedirler.

İleri yaş eğitiminin yaşlı bireyler açısından bir diğer önemi ise, bireylerin aldıkları eğitimler sonrasında yaşam bağlılıklarının artması ve bireylerin yeniden üretebilecekleri konusunda kendilerine güven duymalarının sağlanmasıdır. Böylece hem bireyler hem de toplum bundan fayda sağlayabilecektir. Ayrıca eğitimler aracılığıyla yaşlı bireylerin mevcut kültürel gelişme ve değişimlerden haberdar olması sağlanacak hem de yeni nesillere sahip olunan kültürel değerlerin aktarımı da mümkün olabilecektir. Böylelikle sosyal ve ekonomik yaşamda sağlanan uyum kültürel alanlarda da sağlanmış olacaktır. İleri yaş eğitimi, ülkenin entelektüel düzeyini artırmada, sosyal adalet ilkesinin uygulanmasında, sosyal grupların birbirleri ile yakınlaşmasında, insanların sosyal ve siyasi faaliyetlere katılımlarının artmasında önemli bir etken olmaktadır. Formosa (2010), yaşlı bireylerin eğitim almak için gerek kendilerinden gerekse de toplumdan kaynaklanan engellerin ortadan kaldırılmasında yaşlılık döneminde eğitime katılımın yaygınlaştırılmasının etkisinin büyük olacağını savunmaktadır. Dünyada bireylerin diledikleri ortamlardan ve araçlardan internet erişimlerinin mümkün olması e-öğrenme ve eeğitim biçimindeki çalışmaların yaşlı bireylerin eğitimlerinde sürekliliğin sağlanmasında ve öğrenme faaliyetinin devam etmesinde önemli bir etken olduğunu vurgulamaktadır. Özellikle, Komşu (2012)'nin de ifade ettiği gibi, yaşlı bireylerin mesleki bilgi ve becerilerinin güncellenmesi ile geliştirilmesinde ve yaşlı bireylerin kişisel gelişimlerini sağlayarak sosyo-ekonomik yaşama uyum sağlamalarında ileri yaş eğitimi ve e-öğrenme ortamları önemli bir role sahiptir. Bu önerilerin Türkiye koşullarında gerçekleştirilebilmesi için gereken yasal ve kurumsal düzenlemelerin yapılması ve var olan düzenlemelerin ise geliştirilmesi önemlidir.

Sonuç olarak ileri yaş eğitimiyle yaşlı bireyler topluma aktif olarak katılmış ve sosyal dışlanmadan uzaklaşmış ve içinde yaşadığı toplum ile sosyal ve ekonomik anlamda uyum içerisinde yaşama fırsatı elde etmiş olacaktır. Bu nedenle sadece devletin sunduğu politikaların uygulanması tek başına yeterli değildir. Yerel yönetimlerin de bu konuda paylarına düşen 
sorumluluğu almaları ve yaşlı bireylerin talep ve beklentilerini dikkate alarak uygun öğrenme ortamlarını sağlamaları ve fırsatları sunmaları gerekmektedir. Özetle, yaşlı bireylerin eğitimlerine yönelik alanların ve fırsatların çeşitlendirilmesi ve bunların ülke genelinde yaygınlaştırılması büyük önem taşımaktadır. Son olarak ilave etmek gerekir ki, yaşlılık olgusu nitel ve nicel boyutlarıyla ele alınması gereken bir olgudur. Yalnızca yaşlılık dönemi sorunları ve çözümleri yaklaşımı ile değil; aktif yaşlanma, yaşlı bireylerin yaşam memnuniyetleri, yaşam doyumu ve benzeri olguları tartışan çalışmaların eğitim ile ilişkilendirilmesi yaşlılık dönemini korkulan ve gelmesi arzu edilmeyen yaşamsal bir dönem olmaktan uzaklaştıracaktır. Yaşlılığın, yeni şeyler öğrenmenin önemli olduğu ve buna yeterli zamanın ayrılabildiği bir eğitim dönemi haline gelmesi bir hayal değildir.

\section{KAYNAKÇA}

Aile ve Sosyal Politikalar Bakanlığı. (2012). Özürlü ve Yaşlı Hizmetleri Genel Müdürlüğü Verileri. Ak, M. ve Közleme, O. (2017). Yaşlı Yoksulluğu, Ahi Evran Üniversitesi Sosyal Bilimler Enstitüsü dergisi, 3 (2): 197-208.

Altan, Ö. Z. ve Şişman, Y. (2003). Yaşlılara Yönelik Sosyal Politikalar Kamu-Işs, 7 (2): 2-36.

Ardahan, M., Erkin, Ö., ve Genç, A. (2007). Yaşlıların Algıladıkları Aile Desteğinin Yaşam Doyumlarına Etkisi, (Editör) Kalınkara, V. ve Akın, G., 4. Ulusal Yaşlılık Kongresi Bildiri Kitapçığı içinde (ss. 116-129), Ankara: Yaşlı Sorunları Araştırma Derneği.

Arpacı, F. (2005). Farklı Boyutlarıyla Yaşlılık, Ankara: Türkiye İşçi Emeklileri Derneği Eğitim ve Kültür Yayınları.

Arun, Ö. (2008). Yaşlı Bireyin Türkiye'de Serüveni: Kaliteli Yaşlanma İmkanı Üzerine Senaryolar, Gaziantep Üniversitesi Sosyal Bilimler Dergisi, 7(2): 313-330.

Asi-Karakaş, S. ve Durmaz, H. (2017). Yaşlılık Dönemi Psikolojik Özellikleri ve Moral, Kocatepe Tip Dergisi, 18: 32-36.

Bekısheva, G. T.; Kovalevko, A. N. and Gasparyan, A. G. (2017). E-learning as a Model of Lifelong Education for Older Adults, The European Proceedings of Social and Behavioural Sciences: 67-73.

Bergevin, P. (1967). A Philosophy for Adult Education, New York: Seabury Press.

Boran, A. ve Kurnaz, Z. (2019). Yaşlıların Sosyo-Ekonomik Düzeylerine Göre Sosyal İlişkilerin Aktif Yaşlanma Açısından Analizi, (Editör) Akdemir, N. Geriatri ve Gerantolojiye Disiplinlerarası Yaklaşım, içinde (ss.39-47), (1. Baskı), Ankara: Türkiye Klinikleri.

Canatan, A. (2008). Sosyal Yönleriyle Yaşlılık, İstanbul: Palme Yayıncılık.

Canatan, Ü. ve Boz, H. (2019). Hayat Boyu Öğrenme Etkinliklerine katılımın Aktif Yaşlanmanın Desteklenmesindeki Rolü, Turkish Studies Social Sciences, 14 (3): 343-363.

Ceylan H. (2015). Sosyal Değerden Sosyal Soruna Yaşl1lı: Geleneksel Toplumdan Modern Topluma Değişen Yaşlılık Algısı, (Editör) Ceylan H.: Modern Hayat ve Yaşlılık içinde (ss. 25-54) Ankara: Nobel Yayınevi.

Çetin, S. (2019). Ellibeş Yaş ve Üzeri Bireylerin Emeklilik Algısı ve Emekliliğe Uyum Süreçlerinin İncelenmesi, Yaşlı Sorunları Araştırma Dergisi (YSAD), 12(1): 20-31.

Çilingiroğlu, N. ve Demirel, S. (2004). Yaşlılık ve Yaşlı Ayrımcılı̆̆ı, Turkish Journal of Geriatrics, 7 (4): 225-230. 
Çolak, M. ve Özer, Y. E. (2015). Sosyal Politika Anlamında Aktif Yaşlanma Politikalarının Ulusal ve Yerel Düzeydeki Analizi, Elektronik Sosyal Bilimler Dergisi, 14 (55): 115-124.

Deivitt, M. and Thomas, M. (1996). World Population Profile: 1996. US. Bureau of the Census Report, Washington DC: US Government Printing Office.

Doğru, Y. (2019). Yaşlılık Dönemindeki Bireylerin Yaşlılığa İlişkin Algılarının ve Yaşam Boyu Öğrenme İhtiyaçlarının Değerlendirilmesi, TurkishStudies-Educational Sciences, 13 (27): 499-530.

DPT (2007). Yaşlıların Durumu ve Yaşlanma Ulusal Eylem Planı, Ankara: Sosyal Sektörler ve Koordinasyon Genel Müdürlüğü.

Duman, A. (2000). Yetişkinler Ĕ̆itimi, (2. Baskı), Ankara: Ütopya Yayınevi.

Dülger, İ. (2012). Dünya'da ve Türkiye'de Yaşlılığın Değişen Görünümü, Değişen Politikaları ve Gelişen Aktif Yaşlanma Kavramı, 18-24 Mart Yaşlılara Saygı Haftası Kuşaklararası Dayanışma ve Aktif Yaşlanma Sempozyumu Bildirileri, Mart, Ankara: 37-49.

Dychtwald, K.; Erickson, J. T. and Marison, B. (2004). It's Time to Retire Retirement, Harvard Business Review, 82(3): 48-57.

Ennis-Cole, D. and M.Allen, J. (1998). The Challenges of Training and Retraining Mature Learners, The Journal for Vocational Special Needs Education, 20 (3): 35-42.

Er, D. (2009). Psiko-sosyal Açıdan Yaşl1lık, Fırat Sağlık Hizmetleri Dergisi, 4(1): 131-144.

Formosa, M, (2010), Universities of The Third Age: A Rationale for Transformative Education in Later Life, Journal of Transformative Education, 8 (3): 197-219.

Githens, P. R. (2007). Older Adults and E-learning: Opportunities and Barriers, Benerd School of Education Faculty Articles, 8(4): 329-338.

Görgün Baran, A. (2008). Yaşlılıkta Sosyalizasyon ve Yaşam Kalitesi, Yaşlı Sorunları Araştırma Dergisi, 1 (2): 86-97.

Görgün-Baran, A. ve Kurnaz, Z. (2019). Yaşlıların Sosyo-Ekonomik Düzeylerine Göre Sosyal İlişkilerin Aktif Yaşlanma Açısından Analizi, (Editör) Akdemir N. Geriatri ve Gerantolojiye Disiplinlerarası Yaklaşım içinde (ss.39-47), Ankara: Türkiye Klinikleri.

Gülseren, D., Koçyiğit, H., Erol, A., Kültür, S., Memiş, A. ve Vural, N. (2000). Huzurevinde Yaşamakta Olan Bir Grup Yaşlıda Bilişsel İşlevler, Ruhsal Bozukluklar, Depresif Belirti Düzeyi ve Yaşam Kalitesi, Geriatri Dergisi. 3 (4): 133-140.

Günsoy, G. ve Tekeli, S. (2015). Nüfusun Yaşlanması ve Ekonomik Büyüme İlişkisi: Türkiye Üzerine Bir Analiz, Amme İdaresi Dergisi, 48 (1): 35-87.

Hacettepe Üniversitesi Nüfus Etütleri Enstitüsü (HÜNEE). (2019). 2018 Türkiye Nüfus ve Sağllk Araştırması, Kasım.

Hale, N. (1990). The Older Worker: Effective Strategies for Management and Human Resources Development, San Francisco: Josey-Boss, Book Reviews.

Harwood, J. (2007). Understanding Communication and Aging: Developing Knowledge and Awarness: Sage Publications.

https: //bbc.com/turkce7haberler-dunya-46148247 (Erişim Tarihi: 22.01.2020).

https://sozluk.gov.tr/?kelime= (Erişim Tarihi: 22.01.2020). 
https://www.pewresearch.org/internet/2004/03/28/older-americans-and-the-internet/)Erişim Tarihi: 13.03.2020).

İçli, G. (2004). Huzurevinde Kalan yaşlılar Üzerine Bir Araştırma, Sosyolojik Araştırmalar Dergisi, (1): 5-24.

Kalınkara, V. (2011). Temel Gerantoloji: Yaşlılık Bilimi, Ankara: Nobel Yayıncılık.

Karan, M. A. (2007). Yaşlılık Dönemi ve Problemleri, (Editör) Bayraktar, M. F., Biyolojik, Psikolojik ve Sosyal Açıdan Yaşlanma içinde (ss. 17-30), İstanbul: Ensar Neşriyat.

Kılavuz, M. A. (2002). Yetişkinlik ve Yaşlılık Döneminde Eğitim ve Din Eğitiminin Önemi. Uludă̆ Üniversitesi Illahiyat Fakültesi Dergisi, 11(2): 59-72.

Kinsella, K. and Wan, H. (2009). An Aging World: 2008, International Population Reports: 1-196.

Komşu, U. C. (2014). Yaşlılık, Yaşlı Nüfusun Sorunları ve Yetişkin Eğitimi, Akademik Sosyal Araştırmalar Dergisi, 2 (1): 370-389.

Kontaş, M. (2007). Global Aging \& Life Course Aproach to Active Aging, (Editör) Tufan, İ. Proceedings Book of the 2nd. International Symposium on Social and Applied Gerontology in Turkey. içinde (ss.53-82). Antalya: Gero Yayıncilık.

Korkmaz, A. ve Korkut, G. (2018). Gümüş Ekonomik ve Aktif Yaşlanma Bağlamında Toplumsal Katılım, İş ve Hayat, 4 (8): 257-272.

Kurt, G.; Erkal, Z. ve Yücel-Beyaztaş, F. (2010). Yaşlıların Sorunları ve yaşam Memnuniyeti, Adli Tip Dergisi, 24 (2): 32-39.

Lipphardt, A., Leen-Thomele, E., Coroian, E., and Held, P. (2017). Older Adults and Learning Technology: Innovations in Adults' and Seniors' Education. Innovation in Aging, 1(1): 956.

Macnicol, J. (2005). Age Discrimination: A Historical and Contemporary Analysis, Cambridge: University Press.

Mandıracıoğlu, A. (2010). Dünya'da ve Türkiye'de Yaşlıların Demografik Özellikleri, Ege Tıp Dergisi, 49 (3): 39-45.

Narushima, Liu M. J. and Diestelkamp, N. (2016). Life Long Learning in Active Ageing Discourse: Its Conserving Effect on Wellbeing, Health and Vulnerability, Ageing and Society, 38 (4): 651-675.

Narushima, M. (2008). More than Nickels and Dimes: The Health Benefits of a Community Based Life Long Learning Programme for Older Adults, International Journal of Lifelong Education, 27 (6): 673-692.

Nichols, K. (2001). Optimizing the Silver Collar Worker: In the Shoes of The Older Employee, International Journal of Organization Theory and Behavior, 4(3-4): 225-246.

Özer, M., ve Karabulut, Ö. (2003). Yaşlılarda Yaşam Doyumu, Geriatri Dergisi, 6(2): 72-74.

Özmete, E. (2017). Türkiye'de Kuşaklararası Dayanışmanın Değerlendirilmesi Projesi: Bilgi Notu, Ankara: Ankara Üniversitesi Basımevi

Rizzuto, T. E., and Mohammed, S. (2005), Workplace Technology and the Myth About Older Workers, Paper presented at the Annual Conference of the Society for Industrial and Organizational Psychology, Los Angeles.

Sabancı, A. ve Howe, J. (2009). Yaşlılık ve Eğitim Bilimi: Yeni Bir Bakış Açısı, Çağdaş Eğitim Dergisi, 34 (362): 8-14 
Stein, D. and Rocco, S. T. (2001). The Older Worker Myths and Realities, OH: ERIC Clearing Hause on Adult Career and Vocational Education, No: 18, Columbus.

Stein, D.; Rocco, S. T. and Goldenetz, A. K. (2000). Age and the University Workplace: A Case Study of Remaining, Retiring or Returning Older Workers, Human Resource Development Quarterly, 11 (1): 61-80.

Tekin-Samancı, Ç. ve Kara, F. (2018). Dünya'da ve Türkiye'de Yaşlılık, Uluslararası Bilimsel Araştırmalar Dergisi, 3 (1): 219-229.

Toprak, M. ve Erdoğan, A. (2012). Yaşamboyu Öğrenme: Kavram, Politika, Araçlar ve Uygulama, Yüksek Öğretim ve Bilim Dergisi, 2 (2): 69-91.

Tufan, İ. (2002). Antik Çă̆dan Günümüze Yaşlllık, İstanbul: Aykırı Yayıncılık.

Tufan, İ; Kılavuz, A.; Özgür, Ö.; Ayan, S.; Gürdal, F. Y. ve Engin, B. (2019). Türkiye' de Gerantoloji Atlası: Yaşlı Yoksulluğu ve Yalnızlı Üzerine Bulgular, Geriatrik Bilimler Dergisi, 2 (1): 1-7.

UN. (2002). International Plan of Action of Ageing, Madrid.

UN. (2019). World Population Prospects 2019, Demographic Profiles II.

Uyanık, Y. (2017). Yaşlılık, Yaşlanan Nüfus ve Sosyal Politika, İş ve Hayat Dergisi, 3 (5): 67-100.

Ültanır, E. ve Ültanır, G. (2005). Estonya, İngiltere ve Türkiye'de Yetişkinler Eğitiminde Profesyonel Standartlar, Mersin Üniversitesi Ĕ̆gitim Fakültesi Dergisi, 1 (1): 1-23.

White, J., and Weatherall, A. (2000). A Grounded Theory Analysis of Older Adults and Information Technology, Educational Gerontology, 26(4): 371-386.

WHO. (1998). Health 21-Health for All in the 21st Century, European Health for All Series, (5): 1-36.

WHO. (2017). World Report on Ageing and Health: 1-260.

Yazar, T. (2012). Yetişkin Eğitiminde Hedef Kitle, Dicle Üniversitesi Sosyal Bilimler Enstitüsü Dergisi, 4 (7): 21-30.

Yüceşahin, M. M. (2011). Küresel Bir Süreç Olarak Demografik Dönüşüm Mekansal Bir Değerlendirme, Coğrafi Bilimler Dergisi, 9(1): 11-17. 